\title{
Two Perspectives on the Gender Gap in Computer Engineering: From Secondary School to Higher Education
}

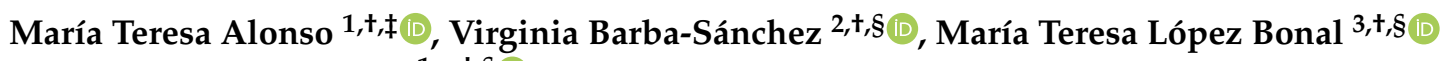 \\ and Hermenegilda Macià $1, *, t, \S(\mathbb{D}$ \\ 1 Department of Mathematics, Universidad de Castilla-La Mancha, 02071 Albacete, Spain; \\ MariaTeresa.Alonso@uclm.es \\ 2 Department of Business Science, Universidad de Castilla-La Mancha, 02071 Albacete, Spain; \\ Virginia.Barba@uclm.es \\ 3 Department of Computing Systems, Universidad de Castilla-La Mancha, 02071 Albacete, Spain; \\ Maria.LBonal@uclm.es \\ * Correspondence: Hermenegilda.Macia@uclm.es; Tel.: +34-967-599-200 \\ + All authors contributed equally to this work. \\ ‡ Current address: Facultad de Farmacia, Avda. Doctor José María Sánchez Ibáñez, s/n, 02071 Albacete, Spain. \\ $\S$ Current address: Escuela Superior de Ingeniería Informática, Edificio Infante D. Juan Manuel, Av. de España, \\ s/n, 02071 Albacete, Spain.
}

\section{check for} updates

Citation: Alonso, M.T.; BarbaSánchez, V.; López Bonal, M.T.; Macià, H. Two Perspectives on the Gender Gap in Computer Engineering: From Secondary School to Higher Education. Sustainability 2021, 13, 10445. https:/ / doi.org/10.3390/su131810445

Academic Editors: Carmen Botella-Mascarell, Anabel Forte Deltell, Emilia López-Iñesta and Silvia Rueda Pascual

Received: 3 August 2021

Accepted: 15 September 2021

Published: 19 September 2021

Publisher's Note: MDPI stays neutral with regard to jurisdictional claims in published maps and institutional affiliations.

Copyright: (c) 2021 by the authors. Licensee MDPI, Basel, Switzerland. This article is an open access article distributed under the terms and conditions of the Creative Commons Attribution (CC BY) license (https:// creativecommons.org/licenses/by/ $4.0 /)$.

\begin{abstract}
In a setting that prioritises the achievement of Sustainable Development Goals (SDG), sustainable development cannot be achieved without the contribution of female talent. This paper is focused on studying the reasons for the gender gap and the offered strategies to reduce it. The debate on the reasons for the low enrolment rates of girls in technological degrees remains open in the literature. This study investigates the causes of why girls do not choose a computer engineering degree and makes a comparison between ex-ante (secondary school) and ex-post (higher education). Based on a survey of students from both secondary school (229) and higher education (171), a quantitative study on gender differences was performed. The chi-squared test was applied to compute the corresponding $p$-value. Gender significant differences concerning goals were found (such as, at secondary school, girls preferred to help people, whereas boys preferred to be rich or to have a lot of holidays), and degree preferences (secondary school girls showed great interest in degrees, such as psychology, criminology and medicine, while boys showed great interest in sports sciences and engineering). However, these differences cannot be attributed to the existence of gender stereotypes, to the poor social image of workers in that field, or to the goals to be achieved within this profession. Some proposals are offered to reduce the gap.
\end{abstract}

Keywords: STEM; ICT; gender gap; secondary education; stereotypes and career choice; scientific and technological vocations in STEM

\section{Introduction}

In a setting that prioritises the achievement of the Sustainable Development Goals (SDG) [1], based on equitable and inclusive education (SDG4), gender equality (SDG5), inclusive employment (SDG8) and the promotion of innovation (SDG9), women globally constitute only $28 \%$ [2] of the workforce in the fields of Science, Technology, Engineering and Mathematics (STEM). There is no consensus in the specialised literature on the reasons for the existence and persistence of this gender gap: Some attribute it to the natural roles found in our gender identity [3]; others assume that the explanation could lie exclusively in cultural patterns [4], while others opt for an elective position that combines both approaches and is based on education [5]. However, from a motivational point of view, what leads girls to be so under-represented in the STEM field?

Our own experience, garnered through activities implemented in recent years on visits to secondary schools to promote women in engineering, has led us to believe that 
girls at secondary school do not typically consider computer science/engineering. We use computer science or computer engineering as synonyms for the same discipline- as an option for their future. Although motivation can be a good predictor of the performance of a given action [6], according to the Theory of Planned Behaviour (TPB) [7], training is also a key aspect, and thus individuals' choice of studies from adolescence will condition their future professional career. This perspective has been addressed in previous studies [8]; however, greater empirical evidence is still required [4], and this is the first contribution of this study. The motivation of this study is to analyse the gender gap in computer science considering ex-ante (secondary school) and exp-post (higher education). Thus, the following research question is posed:

- $\quad$ Research Question 1 (RQ1): Are there differences between boys and girls in goals for the future, when in the world of work (professional field), and in interest in pursing certain studies?

Moreover, this gender gap is especially great in engineering in general, and in computer engineering in particular [9]. With future employment in this field being some of the fastest growing and best paid [2], much more so in the post-COVID-19 era, will women be left behind? Moreover, can the sustainable development advocated by the SDG be achieved without the contribution of female talent? However, the negative image of the computer engineering professionals has traditionally been posited as an element of aversion towards these studies among girls [10]. In this sense, we address the following research question:

- $\quad$ Research Question 2 (RQ2): In the computer science discipline specifically, are there any differences in the perception of boys and girls in terms of a person working in this technological field or in the goals to be achieved by working in this area? Do boys and girls have different perceptions of the characteristics and goals of professionals in the computer science field?

Focusing on girls, although intention is a good predictor of behaviour, studies that make comparisons through ex-ante and ex-post study of computer engineering are scarce [4]. This is a further contribution of this study, and we thus pose our third research question:

- $\quad$ Research Question 3 (RQ3): Do girls who study computer science at university have different goals than secondary school girls who are interested in computer science?

In summary, the main contribution of this research is to provide more new empirical evidence on gender differences between boys and girls in the secondary school setting with respect to their goals and what university studies they should pursue. In addition, we seek to investigate why girls lack interest in computer science, analysing whether this might be influenced by secondary school students' image of persons engaged in computer engineering or the goals to be achieved by working in this field.

Finally, we investigate the motivations that drive girls to choose computer engineering, analysing both the intention to undertake these studies, based on a sample of secondary school students, and the effective behaviour once these studies are chosen, based on a sample of university computer science students. This last point can provide a snapshot to compare possible differences between girls currently studying a computer science degree and girls from secondary school.

The rest of the paper is structured as follows. After this introduction, Section 2 presents the related work that brings together the main contributions of the previous literature and the debate on the reasons for the gender gap, which remains open. Materials and Methods are described in Section 3, while the main results together with the discussion are presented in Section 4. Finally, Section 5 presents our conclusions that cover the limitations and future lines of research.

\section{Related Work}

The study of the existence of a "gender gap" in an educational setting has been a top trending of discussion for years. The specialised literature corroborates the gender 
gap in the field of engineering [11], in general, and computer science, in particular [12,13], and even in the use of [14] technologies. According to the data from the Woman in Digital (WID) Scoreboard [15], this gap is generalised to all STEM graduates and to the current 27 countries of the European Commission (see Figure 1). Various theories have been proposed to explain the reasons for this gap. Some theories, such as the social role theory [16] or the theory on gender stereotypes $[17,18]$, propose that gender traits and stereotypes develop as a result of the differential roles that men and women occupy in society.

Fernándes-César et al. in [19] explored the presence of stereotypes in pre-university students with respect to gender, science, and scientists, and Makarova et al. in [20] explored how gender-science stereotypes can potentially influence young people aspirations to enrol in a STEM major at university; while other theories, such as the person-fit theory [21] or the attraction-selection-attrition (ASA) model [22] suggest that people choose jobs that match their personality, skills and principles.

In this sense, Bakan [23] proposed two dimensions to differentiate the orientations of each gender: agency and communion. Agency (self-efficacy) entails focusing on the self as an autonomous agent, which would describe a more masculine orientation; while communion (community) implies focusing on others and on relationships, describing a more feminine orientation.

$\mathrm{Su}$, Rounds and Amstrong [8] conducted a meta-analysis on the variability of gender differences in vocational interests, concluding that men prefer business-oriented careers, while women prefer people-oriented careers. Thus, the diverse interests, understood as part of the identity of an individual [24], explain, for some authors, the low number of women in some fields of science and engineering [25], thus, justifying these results as natural and inevitable [3].

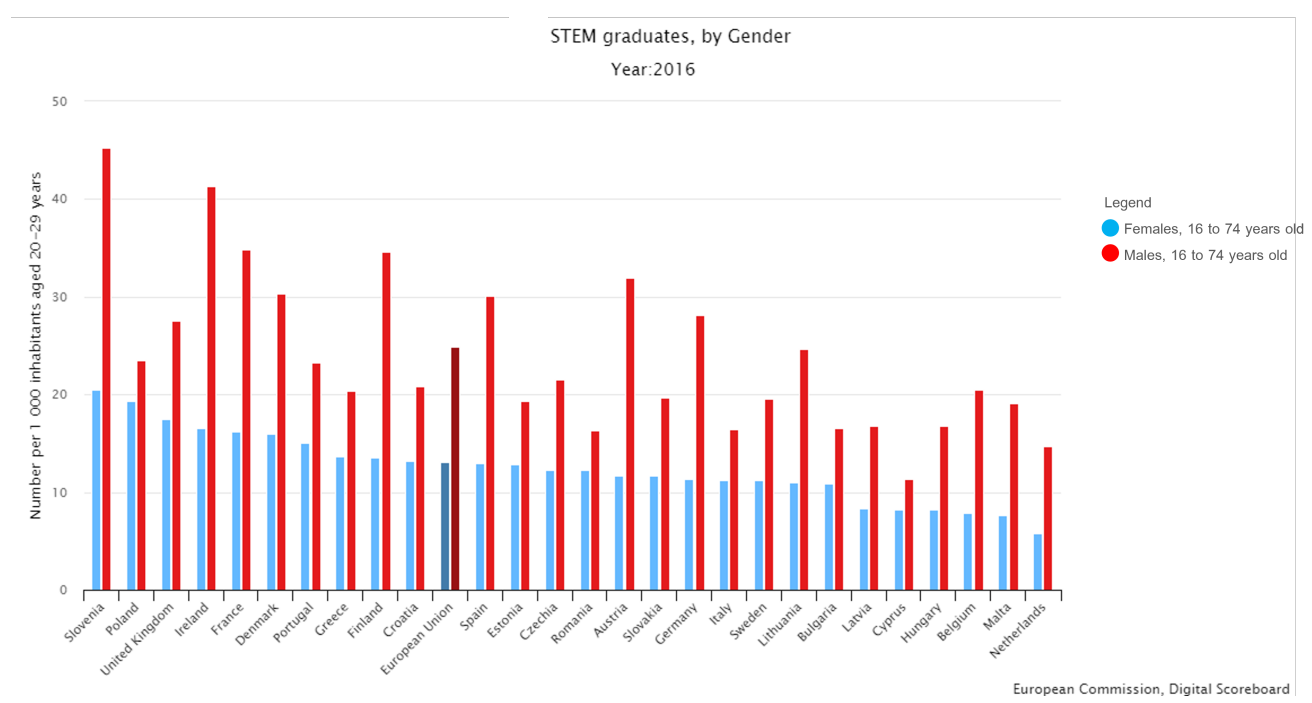

Figure 1. STEM graduates in the European Union by gender (2016).

However, these explanations do not seem convincing in environments where gender equality is fostered. A recent study in the field of Information Theory [5] confirms that increasing the visibility of female role models associated with technology contributes to increasing the rate of enrolment in this type of degree. According to [26], people form interests that are consistent with their identity, self-perception of their capabilities and the role of gender, seeking environments that allow their differentiating characteristics to function effectively and complement each other. In this sense, Ref. [27] stated that girls are more receptive than boys to these contextual influences when considering their educational aspirations.

Recently, authors, such as Bencheva and Kostadinow in [28], have again stressed the importance of changing the perception that girls and, above all, their parents have about STEM careers, since they are the main guide in career choice. Furthermore, Olmedo- 
Torres et al. in [29] concluded that the immediate environment, together with social stereotypes, are the primary reasons for the low presence of girls in STEM studies, relegating preferences to third place.

In the results obtained in these recent studies, contextual and cultural factors continue to take precedence over personal ones, which seems to reaffirm the lack of equality between boys and girls with respect to educational aspirations, as suggested by $\mathrm{Xu}$ in [27], and the need to take measures at different educational levels to mitigate these inequalities. However, the problem is not equally serious in all STEM fields. In this sense, Olmedo-Torres et al. in [29] highlighted that, in some areas, such as computing, not only are women far fewer in number than men, but, in recent years, they have been decreasing.

In the area of computer engineering, many initiatives have been carried out in recent years to promote these studies among girls and women-for instance, Benavent et al. in [30] or Bencheva and Kostadinow in [28]. However, a significant gender gap in the existing ICT (Information and Communications Technology) specialists in the market can still be found (see Figure 2). Bencheva and Kostadinow in [28] recommend the integration of ICT in schools, as a way not only to reduce this gender gap, but also to improve the disposition of both sexes to ICT careers, given the shortage of this type of professional in the current labour market [5].

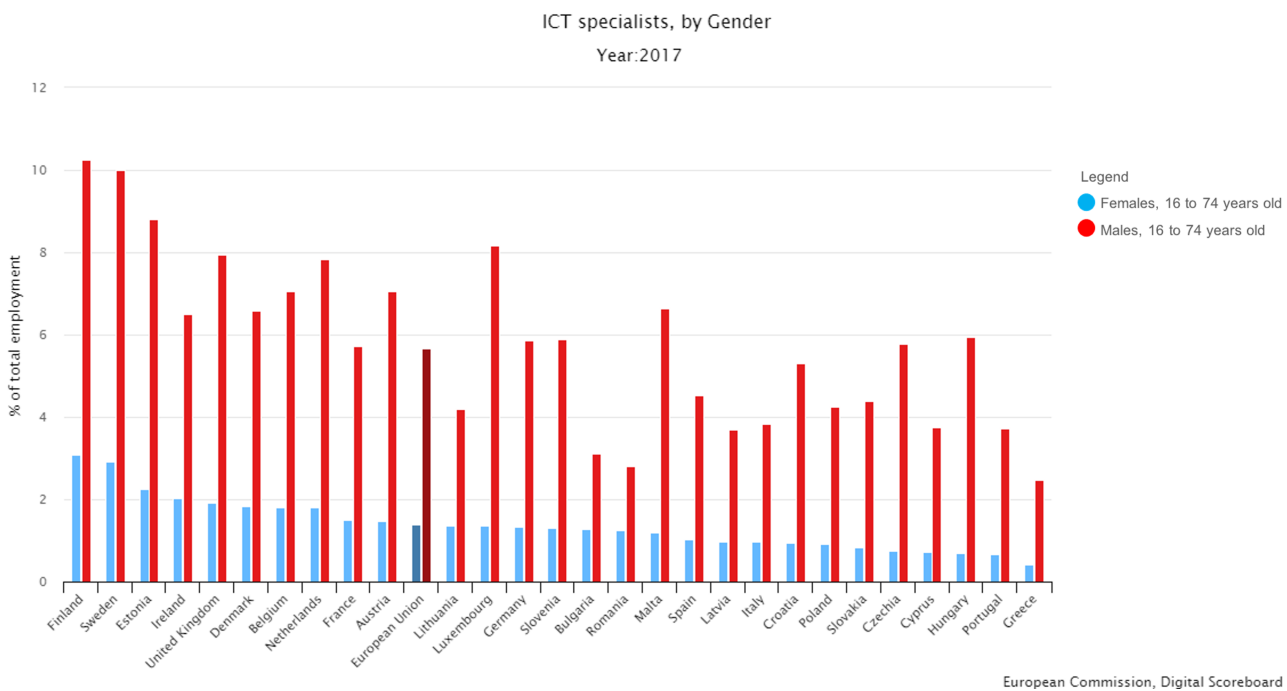

Figure 2. ICT specialists in the European Union by gender (2017).

\section{Materials and Methods}

Our research design was grounded in two phases, one aimed at secondary school students and the other at computer engineering students. This study is based on the work done by Sainz in [31] for Secondary Education, but adapted to our case of interest of computer engineering. In both cases, the students were asked to complete a survey based on the work by Eccles et al. in [32] to examine whether gender differences in educational choices are linked to differences in individuals' expectations for success and subjective task value. We also drew on the work by Eagly et al. in [33] to delve into whether students have preconceived stereotypes of professional work in the field of computer science.

The survey was divided in five parts. The first part concerned respondents' personal data, with gender being the special interest as the focal variable.

- Personal data: Questions about age, gender, year of study, birthplace, parents' studies, etc.

Next, there were four blocks. Each question was rated on a 5-point Likert-type scale, from A (very important/interested, extremely likely) to E (not at all important/interested, extremely unlikely). Block 1 comprised 12 questions on the types of expressive-communal and agent-instrumental goals that the students would like to achieve in the future. 
Additionally, in Block 2, there were 24 questions about their interest in studies, including different areas (STEM, social, etc.).

- Block 1: Achievement of goals in future work.

- Block 2: Interest in different fields of study.

Figure 3 shows the questions of this first part.

\section{SURVEY}

Please, answer the following questions:

High School:

Age:

Year of study: 1 (1 ESO), 2 (2ESO), 3 (3 ESO), 4 (4 ESO), 5 (1 BAC), 6 (2 BAC)

- Sex: (A) Girl (B) Boy

$\begin{array}{llll}\text { - Mother's studies: (A) No formal education } & \text { (B) Primary } & \text { (C) Secondary } & \text { (D) University }\end{array}$

(E) Postgraduate

$\begin{array}{lllll}\text { - Father's studies : } & \text { (A) No formal education } & \text { (B) Primary } & \text { (C) Secondary } & \text { (D) University }\end{array}$

(E) Postgraduate

ON THE RESPONSE SHEET: first Column...21...32

Once you have completed your studies and are working, how important is it for you to achieve each of the following goals?

A (Very important) B (Important) C (Neutral) D (Somewhat important) E (Not at all important)
21. To help people
27. Flexibility of timetable
22. Social recognition
28. To be independent
23. Have a lot of money to be rich
29. To have a lot of holidays
24. To contribute to society
30. To work in teams
25. To overcome challenges
31. To excel in your field
26. To lead projects
32. To travel

ON THE RESPONSE SHEET: second Column...51...78

How interested are you in studying the following degrees at University?

A (Very interested) B (Interested) C (Neutral) D (Somewhat interested) E (Not at all interested)
$\begin{array}{ll}\text { 51. Computer Engineering } & \text { 65. Journalism } \\ \text { 52. Medicine } & \text { 66. Forestry Engineering } \\ \text { 53. Law } & \text { 67. Business Management and Administration } \\ \text { 54. Architecture } & \text { 68. Telecommunication Systems Engineering } \\ \text { 55. Physics } & \text { 69. Pharmacy } \\ \text { 56. English Studies } & \text { 70. Physical Activity and Sports Sciences } \\ \text { 57. Mechanical Engineering } & \text { 71. Electrical Engineering } \\ \text { 58. Sociology and Politics } & \text { 72. Nursing } \\ \text { 59. Aeronautical Engineering } & \text { 73. Agricultural Engineering } \\ \text { 60. Chemistry } & \text { 74. Economics } \\ \text { 61. Mathematics } & \text { 75. Environmental Sciences } \\ \text { 62. Early Childhood Education } & \text { 76. Criminology } \\ \text { 63. Humanities } & \text { 77. Civil Engineering } \\ \text { 64. Veterinary Science } & \text { 78. Psychology }\end{array}$

Figure 3. Survey Part I.

Blocks 3 and 4 focused on computer science/engineering. Specifically, Block 3 contained 18 questions about the respondents' perception of a professional working in the field of computer engineering, while Block 4, in a similar way to Block 1 , comprised 12 questions about the goals it would be possible to reach working in this technological area.

- Block 3: Perception of a professional working in the computer engineering field. 
- $\quad$ Block 4: Goals to be achieved working in computer engineering.

Figure 4 shows the questions of Blocks 3 and 4 .

ON THE RESPONSE SHEET: third Column...101...116

To what extent do you think the following characteristics define the personality of a person working in the field of Computer Engineering?

A (Extremely likely) B (Somewhat likely) C (Neither Likely nor Unlikely) D (Somewhat Unlikely) E (Extremely unlikely)

101. She/he behaves as a leader
102. She/he enjoys working with people
103. She/he loves challenges
104. Obedient
105. Controlling
106. Tolerant
107. Individualist
108. Kind

101. She/he behaves as a leader 102. She/he enjoys working with people

108. Kind
109. Perfectionist

110. Geeky

111. Overemotional

112. Concerned about her/his physical appearance

113. Insensitive

114. Supportive

115. Athletic

116. Selfish

ON THE RESPONSE SHEET: fourth Column ...151...162

To what extent do you think a degree in Computer Engineering would allow you to achieve the following goals?

A (Extremely likely) B (Somewhat likely) C (Neither Likely nor Unlikely) D (Somewhat Unlikely) E (Extremely unlikely)

151. To help people
152. Social recognition
153. To be rich
154. To contribute to society
155. To overcome challenges
156. To lead projects

Figure 4. Survey Part II.

The first part of this study focused on secondary school students. Within the activities related to the program and actions carried out by our University for 11-F (International Day of Women and Girls in Science) (https:/ / www.un.org/en/observances/women-andgirls-in-science-day, accessed on 10 September 2021), the authors of this paper visited several secondary schools in Albacete (Spain) ([34]) and were responsible for supervising the surveys. These surveys were completed by the students on a paper associated to an OMR (Optical Mark Reading). This took place before the activity concerning 11-F. No more than 30 min was spent on completing the survey. The authors gathered and processed the data from students in Compulsory Secondary Education (13-16 years old) in the city of Albacete.

The second part of this study focused on students currently enrolled in the computer engineering degree in Albacete, UCLM (University of Castilla-La Mancha, Spain). In this case, the same survey was provided online using Microsoft Forms of the UCLM and the students completed it under the supervision of a teacher (author of this paper). No more than 15 min were spent on completing the survey. The students were enrolled in first or second year (18-21 years old).

In both secondary school and higher education, students participated voluntarily in the study and were informed about the confidential and anonymous treatment of their responses to the survey. All participants were encouraged to answer the questionnaire as honestly as possible as there were no right or wrong answers. 
All responses provided in each question were compared between girls and boys. The chi-squared test was applied in each case to compute the corresponding $p$-value. A high $p$-value indicates that no differences exists between girls and boys. However, if the $p$-value fulfils $p<0.05$, it indicates that statistically significant differences between girls and boys do exist for that case.

\section{Results and Discussion}

Table 1 shows, for each activity (secondary school or computer engineering students), the number of students that participated (Part), their age (Age), the number of female (Girls) and male students (Boys) and the dates when the survey was administered.

Table 1. Execution data: participants, age, gender and date for each activity.

\begin{tabular}{cccccc}
\hline Students & Age & Girls & Boys & Part & Date \\
\hline Secondary School & $13-16$ & 110 & 119 & 229 & Feb 2018 \& Feb 2019 \\
Computer Eng. & $18-21$ & 21 & 150 & 171 & Nov-Dec 2019 \\
\hline
\end{tabular}

A data analysis study based on the data gathered from the survey of both secondary school and higher education students is shown. We focus on analysing the existence of gender and generational differences in the answers and seek to analyse why girls lacked interest in studying computer engineering. In this way, we present descriptive statistics and the results of the chi-square test of independence used to assess whether there is a significant effect on gender for the four blocks presented in Section 3 in order to respond to RQ1 and RQ2 in both cases (secondary school and higher education students).

The corresponding tables showing the comparative of some relevant questions in each block will be appear in their corresponding sections. The first Column in each table shows the question, the second the percentage of A (very important/very interested/extremely likely) or B (important/interested/somewhat likely) (letter A or B selected) for girls, in Column 3 for boys and in Column 4 the percentage difference. If there is a significant difference at chi-squared test, column 4 is in bold. These three Columns are for secondary school students while Columns 5, 6 and 7 represent the same data for higher education students.

We also provide an analysis of the responses to Block 1 by the secondary school girls showing interest in a computer engineering degree, together with the girls currently studying this degree, in order to respond to RQ3.

\subsection{Goals for the Future (Block 1-RQ1)}

The students had to answer the following question: Once you have finished your studies and are working, how important is it for you to achieve each of the following goals?

From the list of goals in Block 1, Table 2 is presented as a summary of the importance of boys' and girls' goals. As we can see in that table, the three main goals for girls at secondary school are: to help people, to overcome challenges and to be independent. While the main goals for boys are to overcome challenges to be independent and to excel in your field. Figures A1 and A2 in Appendix A show the complete graphics for this block for students at Secondary School.

In the case of students of computer engineering, in the same table, we can see that the main goals of the girls are: to be independent, to travel, to overcome challenges and flexibility of timetable. While the main goals of the boys are to be independent, to overcome challenges and to help people. Figures A9 and A10 in Appendix B show the complete graphics for this block for students at higher education.

Although some differences in the percentage are high and may possibly indicate a trend, a chi-square test was performed to see whether differences exist between gender and goals (see Table 3). In the case of secondary school students, we found differences between importance in girls and boys in to help people, to be rich and to have a large amount of holidays. While in higher education students, the only significant difference was to work in teams. 
Table 2. Comparison of goals (Block 1) to be reached when respondents finish their studies between girls and boys in secondary school and in higher education (RQ1)*.

\begin{tabular}{|c|c|c|c|c|c|c|}
\hline \multirow{2}{*}{ Goal } & \multicolumn{3}{|c|}{ Secondary School } & \multicolumn{3}{|c|}{ Higher Education } \\
\hline & Percent. Girls & Percent. Boys & Differ & Percent. Girls & Percent. Boys & Differ \\
\hline To help people & $84 \%$ & $70 \%$ & $+14 \%$ & $81 \%$ & $83 \%$ & $-2 \%$ \\
\hline To overcome challenges & $79 \%$ & $84 \%$ & $-5 \%$ & $95 \%$ & $85 \%$ & $+10 \%$ \\
\hline To be independent & $74 \%$ & $75 \%$ & $-1 \%$ & $100 \%$ & $89 \%$ & $+11 \%$ \\
\hline To travel & $73 \%$ & $71 \%$ & $+2 \%$ & $100 \%$ & $75 \%$ & $+25 \%$ \\
\hline To contribute to society & $65 \%$ & $57 \%$ & $+8 \%$ & $76 \%$ & $68 \%$ & $+8 \%$ \\
\hline To excel in your field & $64 \%$ & $72 \%$ & $-8 \%$ & $76 \%$ & $73 \%$ & $+3 \%$ \\
\hline Flexibility of timetables & $53 \%$ & $61 \%$ & $-8 \%$ & $95 \%$ & $76 \%$ & $+19 \%$ \\
\hline $\begin{array}{c}\text { To have a large amount } \\
\text { of holidays }\end{array}$ & $48 \%$ & $66 \%$ & $-18 \%$ & $48 \%$ & $59 \%$ & $-11 \%$ \\
\hline To work in teams & $43 \%$ & $57 \%$ & $-14 \%$ & $52 \%$ & $56 \%$ & $-4 \%$ \\
\hline To lead projects & $43 \%$ & $55 \%$ & $-12 \%$ & $81 \%$ & $67 \%$ & $+14 \%$ \\
\hline To be rich & $41 \%$ & $65 \%$ & $-24 \%$ & $67 \%$ & $60 \%$ & $+7 \%$ \\
\hline Social recognition & $29 \%$ & $35 \%$ & $-6 \%$ & $57 \%$ & $56 \%$ & $+1 \%$ \\
\hline
\end{tabular}

Table 3. $p$-Values, effect size and power test for gender vs. goals at secondary studies and higher education *

\begin{tabular}{ccccccc}
\hline \multirow{2}{*}{ Goals (Block 1) } & \multicolumn{3}{c}{ Secondary School } & \multicolumn{3}{c}{ Higher Education } \\
\cline { 2 - 6 } & $p$-Value & Effect Size & Power Test & $p$-Value & Effect Size & Power Test \\
\hline To help people & 0.0015 & 0.2752 & 0.9980 & 0.2874 & 0.1614 & 0.8629 \\
\hline Social recognition & 0.8717 & 0.0735 & 0.6419 & 0.8016 & 0.0983 & 0.1329 \\
\hline To be rich & 0.0001 & 0.3145 & 0.9997 & 0.5187 & 0.1566 \\
\hline To contribute to society & 0.6811 & 0.1002 & 0.7339 & 0.3343 & 0.1788 \\
\hline To overcome challenges & 0.2994 & 0.1495 & 0.8843 & 0.2719 & 0.8516 \\
\hline To lead projects & 0.2527 & 0.1529 & 0.8924 & 0.7566 & 0.1112 \\
\hline Flexibility of timetable & 0.1885 & 0.1638 & 0.9157 & 0.4108 & 0.1434 \\
\hline To be independent & 0.9700 & 0.0507 & 0.5724 & 0.3088 & 0.1564 \\
\hline To have a large amount & 0.0189 & 0.2270 & 0.9865 & 0.5102 & 0.8176 \\
\hline of holidays & 0.1804 & 0.1672 & 0.9221 & 0.045 & 0.1389 \\
\hline To work in teams & 0.2922 & 0.1471 & 0.8783 & 0.1394 & 0.2350 \\
\hline To excel in your field & 0.2118 & 0.1596 & 0.9071 & 0.1369 & 0.1951 \\
\hline To travel & & ${ }^{*}$ In green if $p$-value $<0.05$. & & 0.9725 \\
\hline
\end{tabular}

\subsection{Interest in Studies (Block 2-RQ1)}

The students were now required to answer a question about their interest in studying a degree, in the case of secondary school respondents, in the future, and for higher education (enrolled in a computer engineering degree) about whether they were interested in these degree subjects. Table 4 shows a summary of the interest of boys and girls in studying these degrees. 
Table 4. Comparison of the interest (Block 2) to study for secondary school students or showing interest for higher education students (RQ1)*.

\begin{tabular}{|c|c|c|c|c|c|c|}
\hline \multirow{2}{*}{ Studies } & \multicolumn{3}{|c|}{ Secondary School } & \multicolumn{3}{|c|}{ Higher Education } \\
\hline & Percent. Girls & Percent. Boys & Differ & Percent. Girls & Percent. Boys & Differ \\
\hline Psychology & $70 \%$ & $41 \%$ & $+29 \%$ & $48 \%$ & $41 \%$ & $+7 \%$ \\
\hline Criminology & $65 \%$ & $44 \%$ & $+21 \%$ & $57 \%$ & $34 \%$ & $+23 \%$ \\
\hline Medicine & $65 \%$ & $38 \%$ & $+27 \%$ & $62 \%$ & $50 \%$ & $+12 \%$ \\
\hline Nursing & $57 \%$ & $33 \%$ & $+24 \%$ & $43 \%$ & $25 \%$ & $18 \%$ \\
\hline $\begin{array}{l}\text { Early Childhood } \\
\text { Education }\end{array}$ & $51 \%$ & $33 \%$ & $+18 \%$ & $14 \%$ & $21 \%$ & $-7 \%$ \\
\hline English Studies & $51 \%$ & $27 \%$ & $+24 \%$ & $10 \%$ & $13 \%$ & $-3 \%$ \\
\hline Pharmacy & $48 \%$ & $26 \%$ & $+22 \%$ & $38 \%$ & $22 \%$ & $+16 \%$ \\
\hline Humanities & $35 \%$ & $19 \%$ & $+16 \%$ & $5 \%$ & $8 \%$ & $-3 \%$ \\
\hline $\begin{array}{l}\text { Physical Activity and } \\
\text { Sports Sciences }\end{array}$ & $31 \%$ & $63 \%$ & $-32 \%$ & $38 \%$ & $39 \%$ & $-1 \%$ \\
\hline Mathematics & $30 \%$ & $44 \%$ & $-14 \%$ & $76 \%$ & $60 \%$ & $+16 \%$ \\
\hline Computer Engineering & $26 \%$ & $58 \%$ & $-32 \%$ & - & - & - \\
\hline $\begin{array}{l}\text { Telecommunication } \\
\text { Systems Eng. }\end{array}$ & $25 \%$ & $32 \%$ & $-7 \%$ & $52 \%$ & $67 \%$ & $-15 \%$ \\
\hline Aeronautical Eng. & $24 \%$ & $40 \%$ & $-16 \%$ & $67 \%$ & $61 \%$ & $+6 \%$ \\
\hline Electrical Eng. & $24 \%$ & $47 \%$ & $-23 \%$ & $33 \%$ & $54 \%$ & $-21 \%$ \\
\hline Physics & $20 \%$ & $39 \%$ & $-19 \%$ & $52 \%$ & $59 \%$ & $-7 \%$ \\
\hline Mechanical Eng. & $19 \%$ & $39 \%$ & $-20 \%$ & $48 \%$ & $53 \%$ & $-5 \%$ \\
\hline
\end{tabular}

Secondary school girls showed great interest in degrees, such as psychology, criminology and medicine, while boys showed great interest in physical activity and sports sciences and computer engineering. Figures A3 and A4 (Appendix A) show the complete graphics for the students at secondary schools with respect to their interest in studies.

Girls in higher education were interested in mathematics, aeronautical engineering, medicine and criminology, while boys were interested in telecommunication systems engineering, aeronautical engineering, mathematics and physics. Figures A11 and A12 (Appendix B) show the complete graphics for the students at higher education with respect to their interest in studies.

The chi-square test was conducted in order to determine whether the gender variables of each degree interest were independent. This test showed that the variables were genderdependent in many degrees for Secondary Education. For instance, the boys had more interest in technical degrees, such as computer, mechanical, aeronautical or electrical engineering or physics, and the girls preferred health science degrees, such as medicine, pharmacy or psychology or social studies degrees, such as English studies, early childhood education, humanities or criminology. In contrast, in only one case was there a significant difference in higher education, namely, telecommunication systems engineering. The chi-square $p$-values in both cases for Block 2 can be found in Table 5 . 
Table 5. $p$-Values, effect size and power test for gender vs. studies interest at secondary studies *

\begin{tabular}{|c|c|c|c|c|c|c|}
\hline \multirow{2}{*}{ Degrees (Block 2) } & \multicolumn{3}{|c|}{ Secondary School } & \multicolumn{3}{|c|}{ Higher Education } \\
\hline & $p$-Value & Effect Size & Power Test & $p$-Value & Effect Size & Power Test \\
\hline Computer Engineering & 0.001 & 0.379 & 1.000 & - & - & - \\
\hline Medicine & 0.026 & 0.340 & 1.000 & 0.414 & 0.149 & 0.833 \\
\hline Law & 0.238 & 0.155 & 0.898 & 0.762 & 0.105 & 0.705 \\
\hline Architecture & 0.884 & 0.071 & 0.634 & 0.376 & 0.158 & 0.855 \\
\hline Physics & 0.034 & 0.214 & 0.979 & 0.583 & 0.128 & 0.775 \\
\hline English Studies & 0.004 & 0.261 & 0.996 & 0.568 & 0.132 & 0.786 \\
\hline Mechanical Engineering & 0.003 & 0.263 & 0.997 & 0.382 & 0.153 & 0.842 \\
\hline Sociology and Politics & 0.782 & 0.087 & 0.689 & 0.587 & 0.129 & 0.777 \\
\hline $\begin{array}{l}\text { Aeronautical } \\
\text { Engineering }\end{array}$ & 0.021 & 0.224 & 0.985 & 0.387 & 0.154 & 0.844 \\
\hline Chemistry & 0.618 & 0.108 & 0.759 & 0.868 & 0.087 & 0.649 \\
\hline Mathematics & 0.317 & 0.144 & 0.869 & 0.214 & 0.181 & 0.905 \\
\hline $\begin{array}{l}\text { Early Childhood } \\
\text { Education }\end{array}$ & 0.007 & 0.247 & 0.994 & 0.655 & 0.121 & 0.753 \\
\hline Humanities & 0.006 & 0.251 & 0.994 & 0.926 & 0.076 & 0.619 \\
\hline Veterinary Science & 0.179 & 0.166 & 0.919 & 0.063 & 0.228 & 0.967 \\
\hline Journalism & 0.580 & 0.112 & 0.774 & 0.611 & 0.129 & 0.778 \\
\hline Forestry Engineering & 0.554 & 0.115 & 0.784 & 0.223 & 0.182 & 0.906 \\
\hline $\begin{array}{l}\text { Business Management } \\
\text { and Administration }\end{array}$ & 0.190 & 0.164 & 0.915 & 0.630 & 0.125 & 0.765 \\
\hline $\begin{array}{l}\text { Telecommunication } \\
\text { Systems Eng. }\end{array}$ & 0.388 & 0.134 & 0.844 & 0.037 & 0.243 & 0.978 \\
\hline Pharmacy & 0.002 & 0.268 & 0.997 & 0.635 & 0.124 & 0.763 \\
\hline $\begin{array}{l}\text { Physical Activity and } \\
\text { Sports Sciences }\end{array}$ & 0.061 & 0.328 & 1.000 & 0.333 & 0.164 & 0.868 \\
\hline Electrical Engineering & $1.06 \times 10^{-4}$ & 0.320 & 1.000 & 0.611 & 0.128 & 0.775 \\
\hline Nursing & 0.061 & 0.328 & 1.000 & 0.403 & 0.147 & 0.826 \\
\hline Agricultural Engineering & 0.463 & 0.125 & 0.817 & 0.808 & 0.808 & 0.694 \\
\hline Economics & 0.393 & 0.134 & 0.843 & 0.834 & 0.096 & 0.677 \\
\hline Environmental Sciences & 0.996 & 0.029 & 0.524 & 0.445 & 0.145 & 0.821 \\
\hline Criminology & 0.009 & 0.242 & 0.992 & 0.525 & 0.139 & 0.806 \\
\hline Civil Engineering & 0.282 & 0.149 & 0.882 & 0.240 & 0.178 & 0.899 \\
\hline Psychology & $4.99 \times 10^{-4}$ & 0.390 & 1.000 & 0.309 & 0.168 & 0.879 \\
\hline
\end{tabular}

\subsection{Perception of a Computer Engineering Professional (Block 3-RQ2)}

Table 6 shows the responses in both secondary school and higher education students to the question of how they perceive a professional working in the computer engineering field. 
Table 6. Comparison between girls and boys of the perception of a computer engineering professional (RQ2) *.

\begin{tabular}{|c|c|c|c|c|c|c|}
\hline \multirow{2}{*}{ Perception of CE Worker } & \multicolumn{3}{|c|}{ Secondary School } & \multicolumn{3}{|c|}{ Higher Education } \\
\hline & Percent. Girls & Percent. Boys & Differ & Percent. Girls & Percent. Boys & Differ \\
\hline She/he loves challenges & $77 \%$ & $67 \%$ & $+10 \%$ & $90 \%$ & $88 \%$ & $+2 \%$ \\
\hline Perfectionist & $76 \%$ & $74 \%$ & $+2 \%$ & $95 \%$ & $82 \%$ & $+13 \%$ \\
\hline Kind & $69 \%$ & $68 \%$ & $+1 \%$ & $81 \%$ & $74 \%$ & $+7 \%$ \\
\hline Tolerant & $59 \%$ & $61 \%$ & $-2 \%$ & $67 \%$ & $68 \%$ & $+1 \%$ \\
\hline Individualist & $56 \%$ & $45 \%$ & $+11 \%$ & $52 \%$ & $45 \%$ & $+7 \%$ \\
\hline Obedient & $55 \%$ & $64 \%$ & $-9 \%$ & $71 \%$ & $47 \%$ & $+24 \%$ \\
\hline She/he enjoys working with people & $51 \%$ & $56 \%$ & $-5 \%$ & $52 \%$ & $62 \%$ & $-10 \%$ \\
\hline Supportive & $49 \%$ & $45 \%$ & $+4 \%$ & $67 \%$ & $63 \%$ & $+4 \%$ \\
\hline She/he behaves as a leader & $43 \%$ & $57 \%$ & $-14 \%$ & $62 \%$ & $74 \%$ & $-12 \%$ \\
\hline Geeky & $36 \%$ & $42 \%$ & $-6 \%$ & $43 \%$ & $52 \%$ & $-12 \%$ \\
\hline Controlling & $35 \%$ & $45 \%$ & $-9 \%$ & $52 \%$ & $39 \%$ & $+13 \%$ \\
\hline
\end{tabular}

The table shows that the top three items in all four cases (Columns 2, 3, 5 and 6) are the same: She/he loves challenges, perfectionist and kind, but with a different percentage, being higher in girls than in boys and in higher education than in secondary school students. If we analyse the differences based on gender, in secondary school, the maximum difference between boys and girls is in She/he behaves as a leader with $-14 \%$. In higher education the maximum difference is in Obedient with $+24 \%$. However, according to the chi-square test of independence, the only significant difference related to gender is Perfectionist for higher education students. Table 7 shows the results of the chi-square test of independence about the questions of Block 3.

Table 7. $p$-Values, effect size and power test for gender vs. perception of a worker in computer engineering *

\begin{tabular}{|c|c|c|c|c|c|c|}
\hline \multirow{2}{*}{ Perception of CE Worker (Block 3) } & \multicolumn{3}{|c|}{ Secondary School } & \multicolumn{3}{|c|}{ Higher Education } \\
\hline & $p$-Value & Effect Size & Power Test & $p$-Value & Effect Size & Power Test \\
\hline She/he behaves as a leader & 0.1199 & 0.1788 & 0.9417 & 0.5417 & 0.1297 & 0.7789 \\
\hline She/he enjoys working with people & 0.1851 & 0.1645 & 0.9169 & 0.8126 & 0.0986 & 0.6852 \\
\hline She/he loves challenges & 0.1882 & 0.1639 & 0.9157 & 0.8101 & 0.9240 & 0.6855 \\
\hline Obedient & 0.5320 & 0.1174 & 0.7922 & 0.2544 & 0.1689 & 0.8797 \\
\hline Controlling & 0.3946 & 0.1336 & 0.8420 & 0.3743 & 0.1575 & 0.8537 \\
\hline Tolerant & 0.7012 & 0.0978 & 0.7255 & 0.3243 & 0.1591 & 0.8575 \\
\hline Individualist & 0.3247 & 0.1426 & 0.8668 & 0.6712 & 0.1163 & 0.7390 \\
\hline Kind & 0.6035 & 0.1092 & 0.7651 & 0.7881 & 0.1053 & 0.7056 \\
\hline Perfectionist & 0.8716 & 0.0736 & 0.6420 & 0.0365 & 0.2647 & 0.9884 \\
\hline Geek & 0.8835 & 0.0714 & 0.6348 & 0.2299 & 0.1823 & 0.9066 \\
\hline Overemotional & 0.6386 & 0.1052 & 0.7513 & 0.1339 & 0.2024 & 0.9387 \\
\hline $\begin{array}{l}\text { Concerned about her / his physical } \\
\text { appearance }\end{array}$ & 0.8937 & 0.0694 & 0.6283 & 0.3653 & 0.1556 & 0.8490 \\
\hline Insensitive & 0.1876 & 0.1640 & 0.9160 & 0.9850 & 0.0489 & 0.5525 \\
\hline Supportive & 0.4321 & 0.1290 & 0.8286 & 0.4198 & 0.1433 & 0.8173 \\
\hline Athletic & 0.3607 & 0.1378 & 0.8541 & 0.5262 & 0.1377 & 0.8018 \\
\hline Selfish & 0.2464 & 0.1539 & 0.8946 & 0.7586 & 0.1044 & 0.7026 \\
\hline
\end{tabular}


Figures A5 and A6 (Appendix A) show the graphics for Block 3 in the case of students at secondary school and Figures A13 and A14 (Appendix B) in the case of students at higher education.

\subsection{Goals in Working in the Computer Engineering Field (Block 4-RQ2)}

In this case, we asked about the goals that can be achieved by working in the computer engineering field, according to the girls and boys in secondary school and higher education. Table 8 shows a summary of the most relevant goals. We can again observe in this table that the percentage of A or B in the Likert scale is higher in higher education students than in secondary school students. The top four goals in secondary school students are: to overcome challenges, to lead projects, to help people and to excel in your field, with the latter being the most popular among secondary school boys.

There is an only significant difference in the secondary school group, to be rich, with $-18 \%$. This difference is reversed in higher education at $+5 \%$. Another difference, with $+14 \%$, in secondary school is to contribute to society, which decreases to $+8 \%$ in higher education. In higher education, the top two goals are the same than in secondary school for the girls, and the third one is to be independent. For undergraduate boys, the top two goals are to overcome challenges and to help people. There are not significant differences according chi-squared test in the case of higher education students. All chi-square $p$-values for Block 4 are in Table 9.

Figures A7 and A8 (Appendix A) show the graphics for the responses concerning Block 4 in the case of students at secondary school and Figures A15 and A16 (Appendix B) in the case of students at higher education.

Table 8. Comparison between girls and boys of the goals they believe can be achieved by being a computer engineering professional (RQ2) in secondary school and in higher education *.

\begin{tabular}{|c|c|c|c|c|c|c|}
\hline \multirow{2}{*}{ Goal Working in CE } & \multicolumn{3}{|c|}{ Secondary School } & \multicolumn{3}{|c|}{ Higher Education } \\
\hline & Percent. Girls & Percent. Boys & Differ & Percent. Girls & Percent. Boys & Differ \\
\hline To overcome challenges & $77 \%$ & $67 \%$ & $+10 \%$ & $95 \%$ & $86 \%$ & $+9 \%$ \\
\hline To lead projects & $75 \%$ & $68 \%$ & $+7 \%$ & $95 \%$ & $80 \%$ & $+15 \%$ \\
\hline To help people & $71 \%$ & $62 \%$ & $+9 \%$ & $81 \%$ & $81 \%$ & $0 \%$ \\
\hline To excel in your field & $69 \%$ & $74 \%$ & $-5 \%$ & $81 \%$ & $78 \%$ & $+3 \%$ \\
\hline To contribute to society & $63 \%$ & $49 \%$ & $+14 \%$ & $75 \%$ & $67 \%$ & $+8 \%$ \\
\hline To work in teams & $57 \%$ & $61 \%$ & $-4 \%$ & $75 \%$ & $80 \%$ & $-5 \%$ \\
\hline To be independent & $56 \%$ & $61 \%$ & $-5 \%$ & $86 \%$ & $80 \%$ & $+6 \%$ \\
\hline Social recognition & $47 \%$ & $48 \%$ & $+1 \%$ & $81 \%$ & $70 \%$ & $+11 \%$ \\
\hline To be rich & $38 \%$ & $56 \%$ & $-18 \%$ & $81 \%$ & $76 \%$ & $+5 \%$ \\
\hline Flexibility of timetable & $38 \%$ & $50 \%$ & $-12 \%$ & $71 \%$ & $72 \%$ & $-1 \%$ \\
\hline To travel & $38 \%$ & $40 \%$ & $-2 \%$ & $67 \%$ & $64 \%$ & $+3 \%$ \\
\hline $\begin{array}{c}\text { To have a large amount } \\
\text { of holidays }\end{array}$ & $33 \%$ & $39 \%$ & $-6 \%$ & $43 \%$ & $47 \%$ & $-4 \%$ \\
\hline
\end{tabular}

* In bold the most relevant results. 
Table 9. $p$-Values, effect size and power test for gender vs. goals working in computer engineering *

\begin{tabular}{|c|c|c|c|c|c|c|}
\hline \multirow{2}{*}{ Goals Working in CE Field } & \multicolumn{3}{|c|}{ Secondary School } & \multicolumn{3}{|c|}{ Higher Education } \\
\hline & $p$-Value & Effect Size & Power Test & $p$-Value & Effect Size & Power Test \\
\hline To help people & 0.5869 & 0.1111 & 0.7715 & 0.3193 & 0.1566 & 0.8516 \\
\hline Social recognition & 0.3264 & 0.1423 & 0.8662 & 0.7031 & 0.1114 & 0.7242 \\
\hline To be rich & 0.0018 & 0.2739 & 0.9979 & 0.4163 & 0.1384 & 0.8039 \\
\hline To contribute to society & 0.0890 & 0.1877 & 0.9540 & 0.7176 & 0.1111 & 0.7233 \\
\hline To overcome challenges & 0.3384 & 0.1407 & 0.8619 & 0.9620 & 0.0592 & 0.5753 \\
\hline To lead projects & 0.4931 & 0.1219 & 0.8066 & 0.7476 & 0.1101 & 0.7202 \\
\hline Flexibility of timetable & 0.2736 & 0.1498 & 0.8849 & 0.6152 & 0.1213 & 0.7542 \\
\hline To be independent & 0.6059 & 0.1090 & 0.7642 & 0.9250 & 0.0809 & 0.6326 \\
\hline $\begin{array}{c}\text { To have a large amount of } \\
\text { holidays }\end{array}$ & 0.6862 & 0.0996 & 0.7318 & 0.8161 & 0.0970 & 0.6804 \\
\hline To work in teams & 0.8828 & 0.0715 & 0.6352 & 0.2999 & 0.1649 & 0.8710 \\
\hline To excel in your field & 0.4143 & 0.1312 & 0.8350 & 0.4118 & 0.1480 & 0.8296 \\
\hline To travel & 0.4579 & 0.1260 & 0.8194 & 0.3733 & 0.1557 & 0.8494 \\
\hline
\end{tabular}

4.5. Goals to Achieve in the Future for Girls in Computer Engineering: From Secondary School to Higher Education (RQ3)

In this case, for secondary school girls who find studying computer engineering very interesting or interesting (A or B in the survey), we analysed whether they have different goals for the future than the girls currently studying computer engineering at university. Table 10 summarises and compares these results. Analysing the differences in those girls between secondary school and higher education, the values in Column 4 of Table 10 show that the percentages in higher education are higher than for secondary school, except in the case of to have a large amount of holidays. the largest differences, selecting letter A or B in the survey, are in: to be independent $(-45 \%)$, to lead projects $(-43 \%)$ and flexibility of timetable $(-43 \%)$; to travel $(-31 \%)$ and to be rich $(-29 \%)$ are also noteworthy. Notice that $100 \%$ of the girls studying computer engineering have goals to be independent and travel.

Table 10. Comparison between girls (who like computer engineering) of the goals to be reached in the future (RQ3) for secondary school and higher education students.

\begin{tabular}{cccc}
\hline CE Girls' Goals in the Future & Secondary School Percent. & Higher Education Percent. & Differ \\
\hline To overcome challenges & $79 \%$ & $95 \%$ & $-16 \%$ \\
\hline To excel in your field & $72 \%$ & $76 \%$ & $-4 \%$ \\
\hline To help people & $72 \%$ & $81 \%$ & $-9 \%$ \\
\hline To travel & $69 \%$ & $100 \%$ & $-31 \%$ \\
\hline To contribute to society & $59 \%$ & $76 \%$ & $-45 \%$ \\
\hline To be independent & $55 \%$ & $100 \%$ & $+4 \%$ \\
\hline To have a large amount of holidays & $52 \%$ & $48 \%$ & $-43 \%$ \\
\hline Flexibility of timetable & $52 \%$ & $95 \%$ & $-12 \%$ \\
\hline Social recognition & $45 \%$ & $57 \%$ & $-11 \%$ \\
\hline To work in teams & $41 \%$ & $52 \%$ & $-43 \%$ \\
\hline To lead projects & $38 \%$ & $81 \%$ & $-29 \%$ \\
\hline To be rich & $38 \%$ & $67 \%$ & \\
\hline
\end{tabular}


Figure 5 shows the responses for the girls at secondary school interested in computer science, while Figure 6 shows the responses for girls already studying computer engineering. We could only compare 29 subjects in secondary school vs. 21 in higher education, so we could not apply the chi-square test of independence for the two samples.

Those figures show that three main goals of these girls at secondary school are to overcome challenges, to excel in your field and to help people, while the main goals for the girls currently studying computer engineering are to travel, to be independent, to overcome challenges and flexibility of timetable.

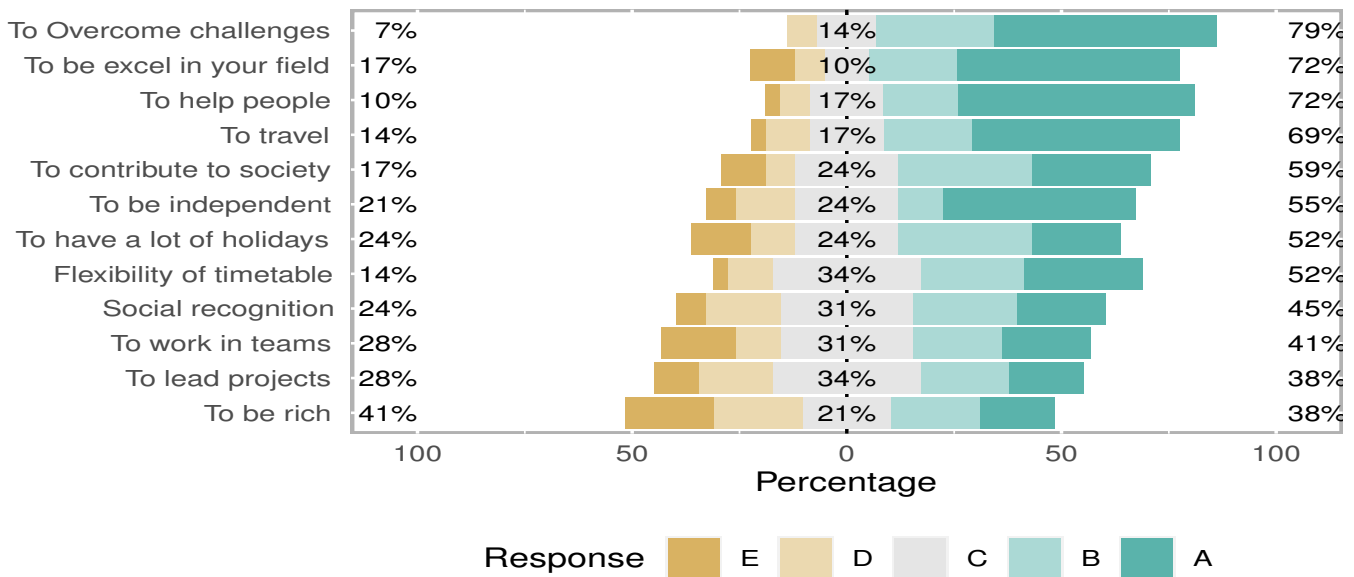

Figure 5. Goals to reach in the future for the girls interested in CE at Secondary School.

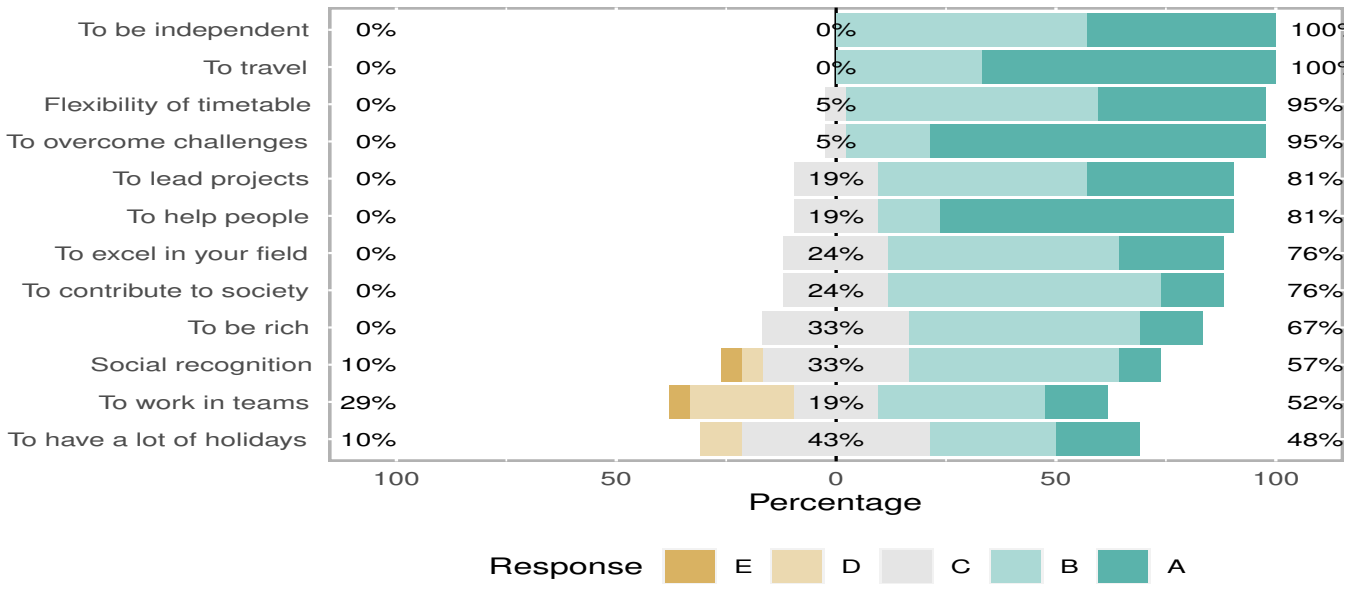

Figure 6. Goals to reach in the future for girls studying computer engineering.

\section{Conclusions}

According to the Research Questions posed in Section 1 and the results in Section 4, we show the conclusions by the blocks described in Section 3. Regarding the goals for the future (Block 1), it can be seen that boys and girls in secondary school share the common goal of overcoming challenges and being independent. Girls place more importance on helping people than boys, and boys are interested in excelling in their field. In contrast, the goals between undergraduate boys and girls are more aligned.

Regarding interest in studies (Block 2), we can conclude that the tendency is confirmed that secondary school boys and girls have different interests in different degrees, while boys show a greater interest in engineering degrees, girls do not have it as a priority, preferring health-related or social degrees. On the other hand, there is no significant difference between boys and girls at higher education in the interest of the degrees because they are undergraduate colleagues. 
Regarding the perception of a computer engineering professional (Block 3), both secondary school girls and boys do not perceive the computer scientist as a geeky person, but as a person who loves challenges, perfectionist and kind. This debunks one of the myths that they do not choose computer science because they think computer scientists are geeks. Undergraduate students (girls and boys) have the same perceptions.

When they are asked about the goals in working in the computer engineering field (block 4), the top preferences are the same in secondary school for boys and girls; however, boys perceive the goal to be rich more than the girls, whereas girls perceive the goal to contribute to society more than the boys. Given this gender gap in computer science, SDG5 about gender equality is hardly achievable in the near future, and thus new strategies to enhance women's participation in computer science are needed. For the higher education students, the answers were more aligned.

Regarding goals to achieve in the future for girls in CE: from secondary school to higher education (RQ3, Block 1), we can conclude that secondary school and higher education girls consider computer science as a way to achieve different goals. In secondary school, girls consider computer science as a way to overcome challenges, to excel in your field and to help people, while, in higher education, it is a means to travel, to be independent and to have flexibility in your timetable.

This is due to the fact that both groups of girls are at different stages of their lives and, therefore, seek different goals. The higher education girls perceive computer science as a degree that will allow them to work and become independent as well as to travel and to make their personal lives more flexible. On the other hand, secondary school girls perceive these goals as still very distant. This difference in objectives cannot be considered to be due to the fact that the profile of the girl who intends to study computer science does not correspond exactly to the profile of the girl who is studying this degree, and this should be addressed in future research.

In many cases, those responsible for computer science studies blame girls' lack of interest in these studies on the mistaken perception of the goals that can be achieved through this profession or on gender stereotypes. However, in line with [29], the results of this study indicate there are no significant differences in these issues. Secondary school students, both boys and girls, have no doubt that pursuing a computer engineering career can help them make an important contribution to society.

This study has some limitations. Although the number of responses assessed was moderate, and the sample of students is representative of the typical enrolment in secondary school and computer engineering degree, the study was limited to the city of Albacete (Spain) over two years. Some aspects could be improved, such as the context, considering other towns/cities, and also the number of girls in both surveys.

Given that previous research has underlined the influence of figures of reference [5,27], such as parents, in the choice of career and the intention of studying computer engineering, future research should take into account the possibility of including mediating and moderating variables in the relationships analysed to improve the explanation of the results obtained.

As future work, we plan to improve this study by considering a more psychological approach, including variables relating to cognitive models by gender or a social approach, including variables with respect to the socio-economical level of the family of the students and other demographic variables in line with those proposed by [19]. Activities focused on promoting STEM among female students are crucial; however, the problem is that the work of female researchers promoting STEM areas would be more valued, as López and Pereira indicated in [35]. 
A key point to overcome this gender gap is to eliminate, in primary school, the negative attitude of girls toward mathematics [36]. Another point is that the integration of computer science from primary education should be a priority for educational authorities [28], forming part of the basic competences of any student. It is important to introduce computational thinking in all levels of the Educational system. This, together with innovative educational methodologies, such as Project Based Learning [37], can be useful to encourage the introduction of computer skills in schools by bringing them closer to problems in their environment.

Finally, with regard to recommendations for the directors of educational institutions of secondary and higher education, it would be appropriate to foster young people's interest in computer science, such as through the design thinking workshop proposed by Kijima et al. in [38].

Life has changed, and today, more than ever, society needs computer engineering professionals in order to continue to function in conditions of safety and health. The idea that we can help people through computer science studies is now much more deeply rooted across all the population. Furthermore, it is important to insist that computer engineering is a crucial key to reach the goal of helping people in many different ways and we, in our role as teachers, have to make girls aware of this, as early as possible.

Unfortunately, COVID-19 has brought about a significant change in our lives; however, it has also highlighted the importance of computer science in our daily lives, contributing to improving the perception of the social functions that can be reached with this discipline. This is a good opportunity to focus on this and to reduce the gender gap in computer science.

Author Contributions: Conceptualization, M.T.A. and V.B.-S.; methodology, M.T.A. and V.B.-S.; software, M.T.A.; validation, V.B.-S., M.T.L.B. and H.M.; formal analysis, M.T.A. and V.B.-S.; investigation, M.T.L.B. and H.M.; resources, V.B.-S. and M.T.L.B.; data curation, M.T.A., M.T.L.B. and H.M.; writing—original draft preparation, M.T.L.B. and H.M.; writing—review and editing, M.T.A. and H.M.; visualization, M.T.A.; supervision, V.B.-S. and M.T.A.; project administration, M.T.L.B. and H.M.; funding acquisition, V.B.-S. and H.M. All authors have read and agreed to the published version of the manuscript.

Funding: This research was supported in part by UCLM group research grants 2021-GRIN-30993 and 2020-GRIN-28793, cofinanced with the European Union FEDER funds.

Institutional Review Board Statement: Not applicable.

Informed Consent Statement: Not applicable.

Data Availability Statement: The data supporting the reported results in the present study will be available on request from the corresponding author or the first author.

Acknowledgments: We would like to thank the students collaborated in this study and our colleagues who participated in 11 February (International Day of Women and Girls in Science).

Conflicts of Interest: The authors declare no conflict of interest. 
Appendix A. Data Analysis Figures for Secondary School Students

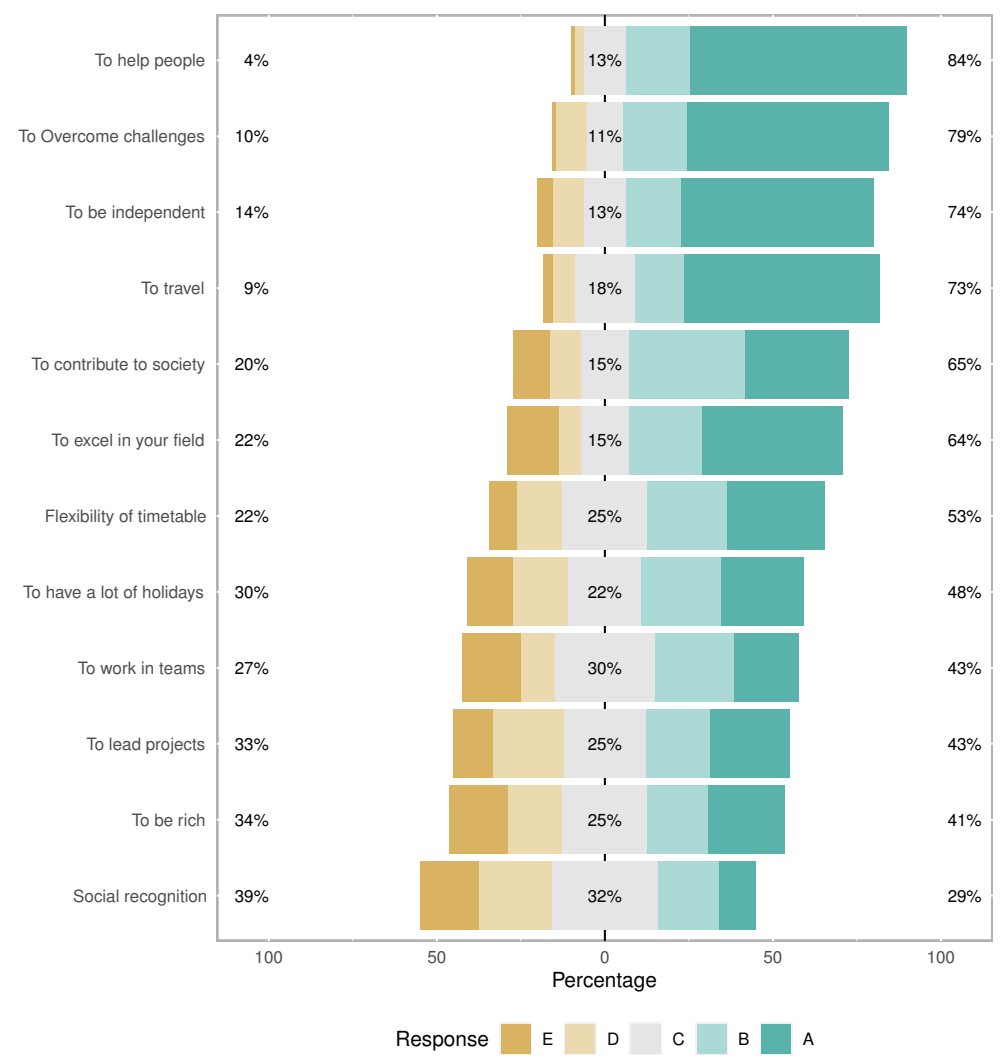

Figure A1. Goals to reach in the future in secondary school girls (Block 1).

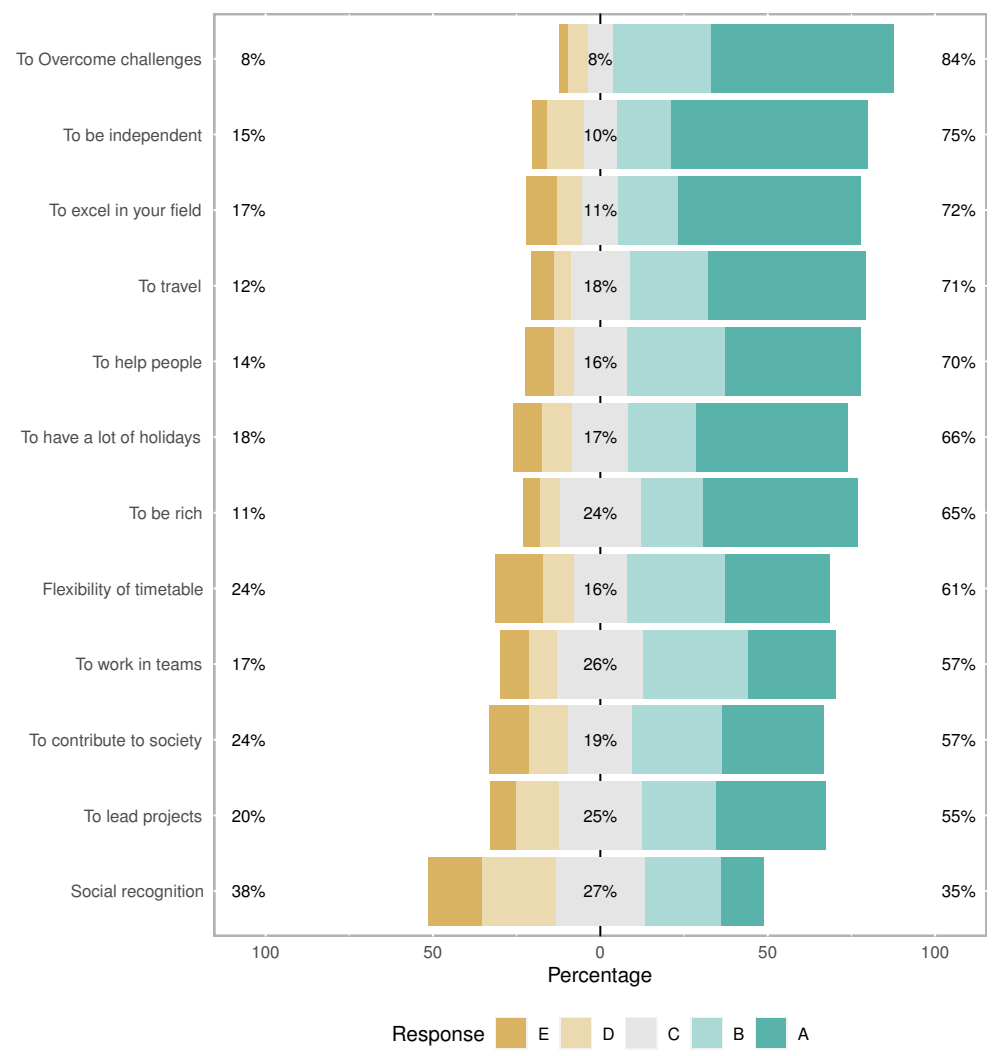

Figure A2. Goals to reach in the future in secondary school boys (Block 1). 


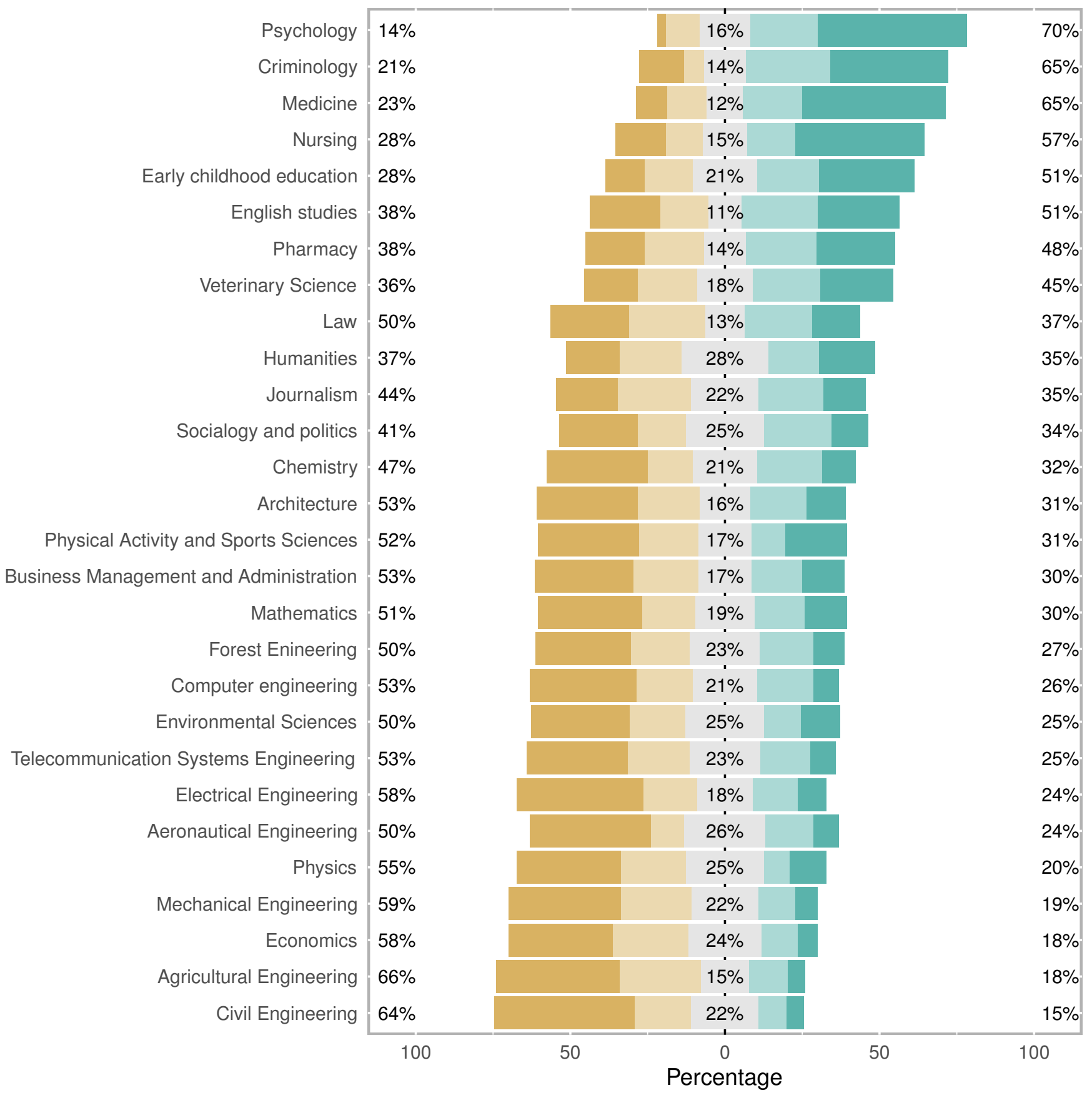

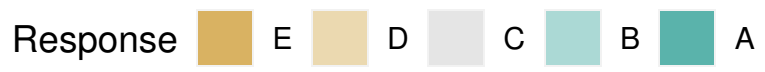

Figure A3. Secondary school girls' interest in studies (Block 2). 

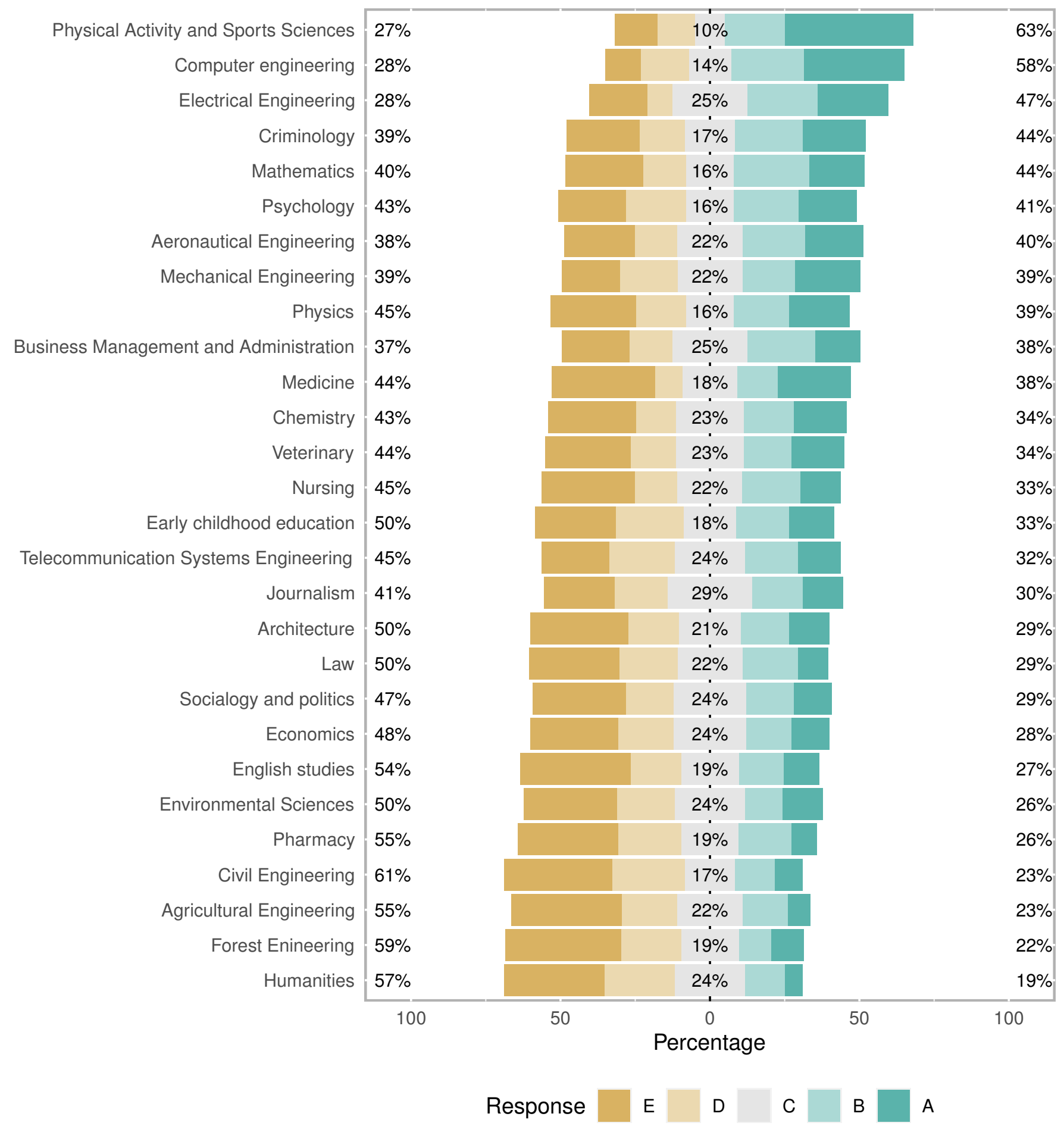

Figure A4. Secondary school boys' interest in studies (Block 2). 


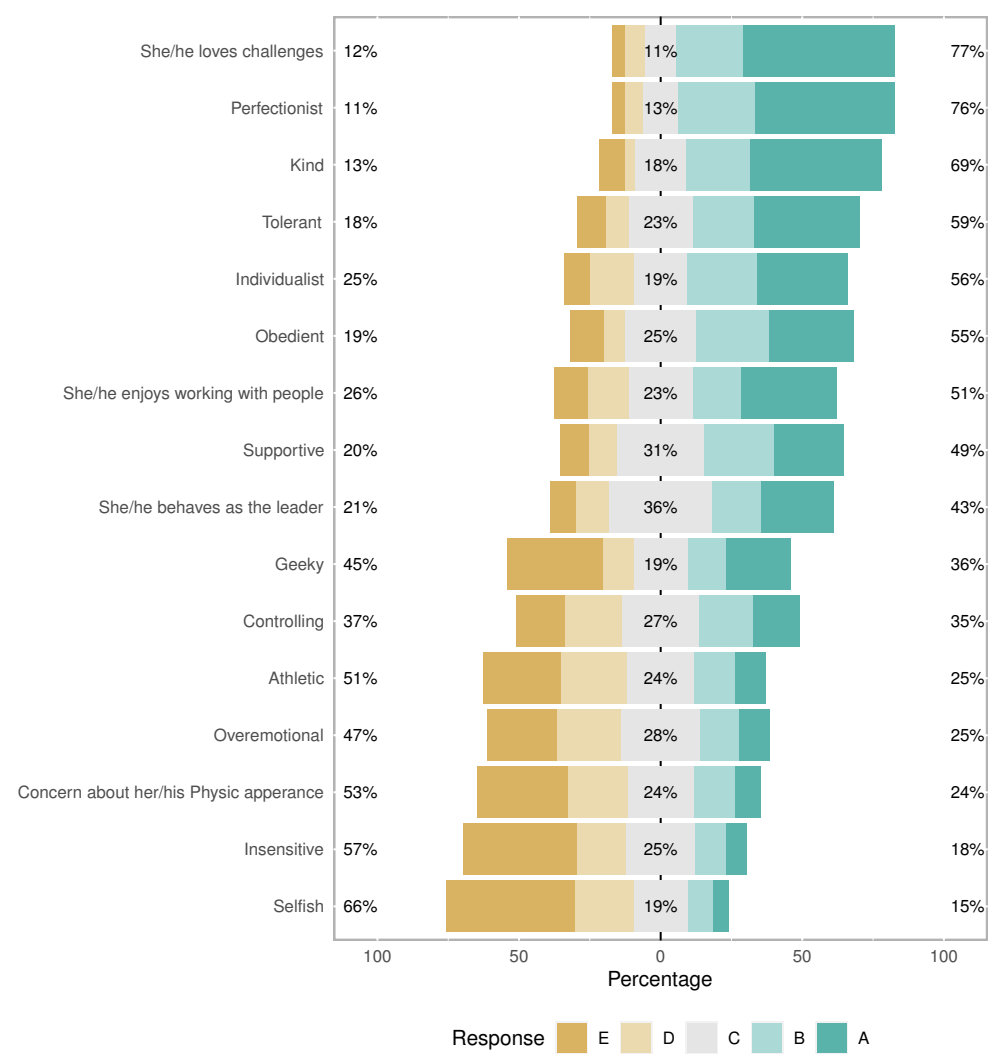

Figure A5. Secondary school girls' perception of a professional who works in computer science (Block 3).

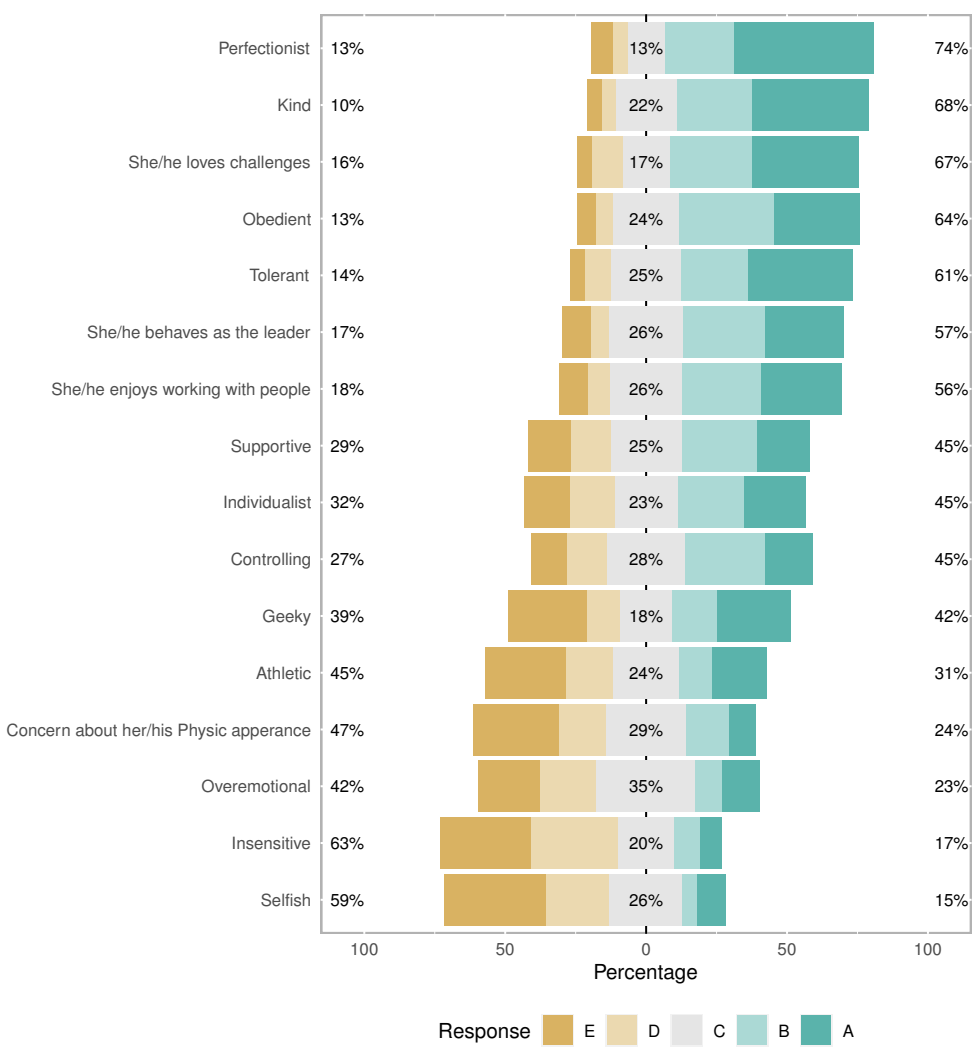

Figure A6. Secondary school boys' perception of a professional who works in computer science (Block 3). 


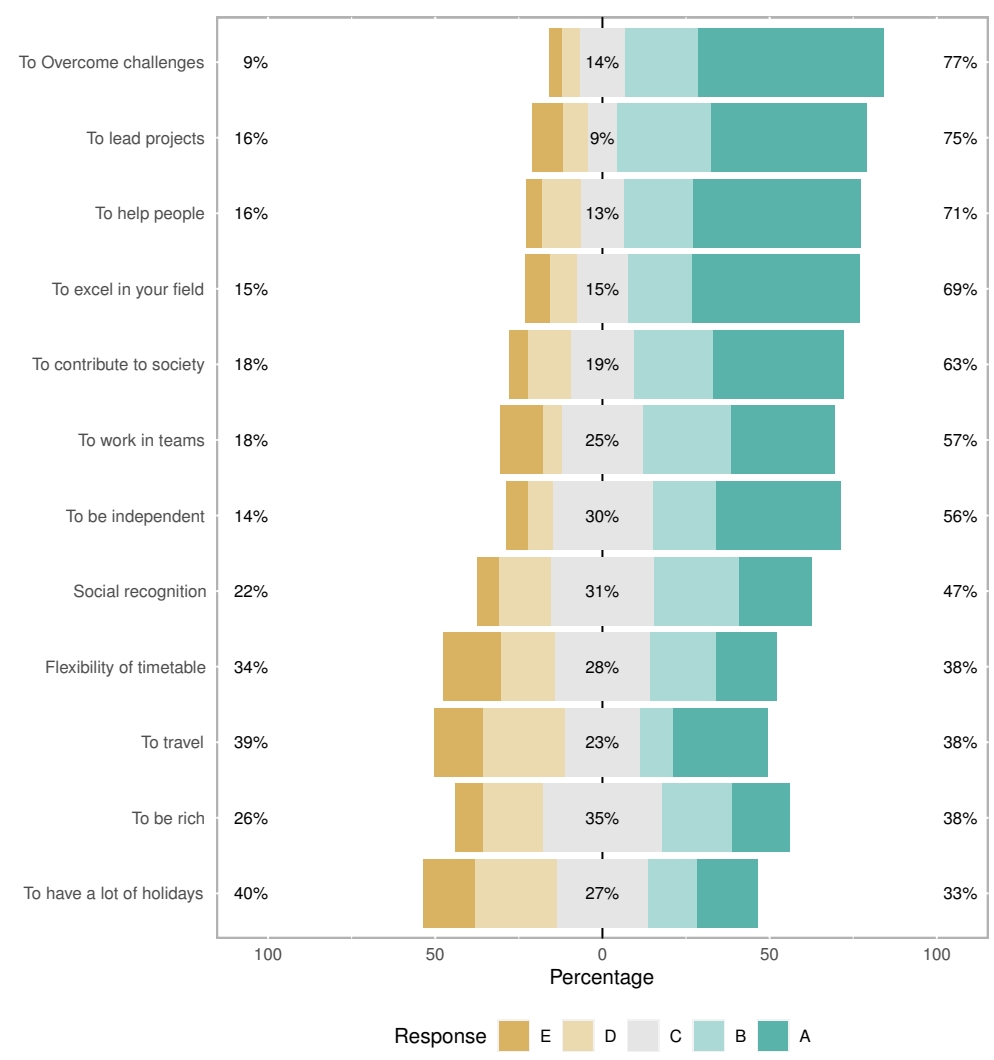

Figure A7. Secondary school girls' perception of goals that can be achieved by working in computer engineering (Block 4).

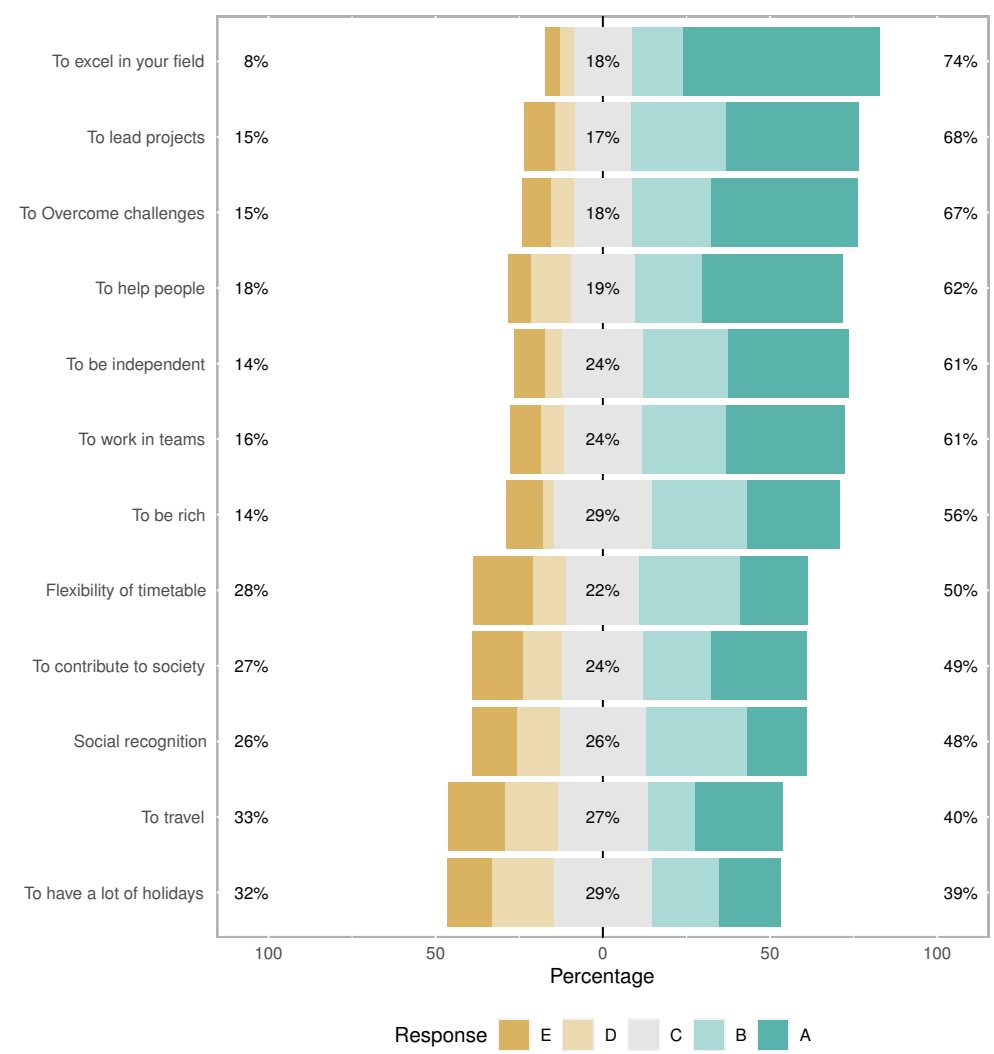

Figure A8. Secondary school boys' perception of goals that can be achieved by working in computer engineering (Block 4). 
Appendix B. Data Analysis Figures for Higher Education Students

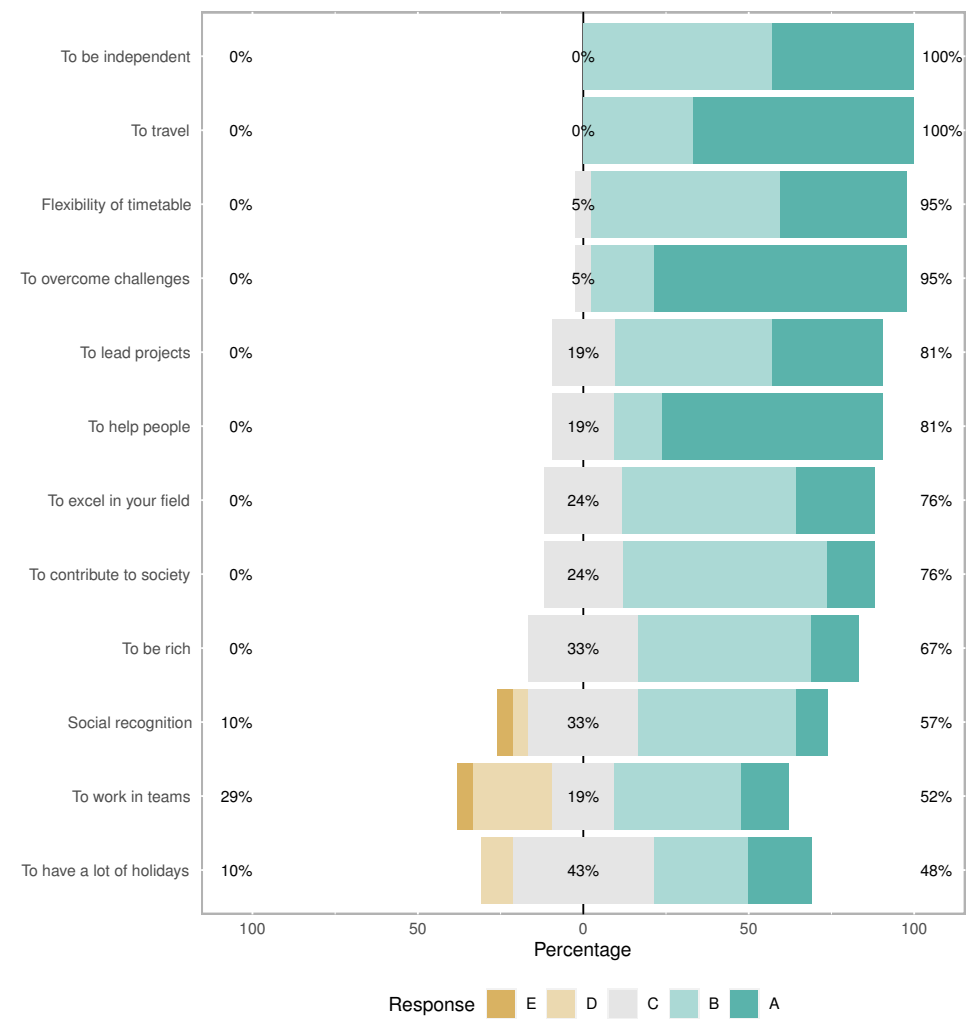

Figure A9. Goals to reach in the future for higher education girls (Block 1).

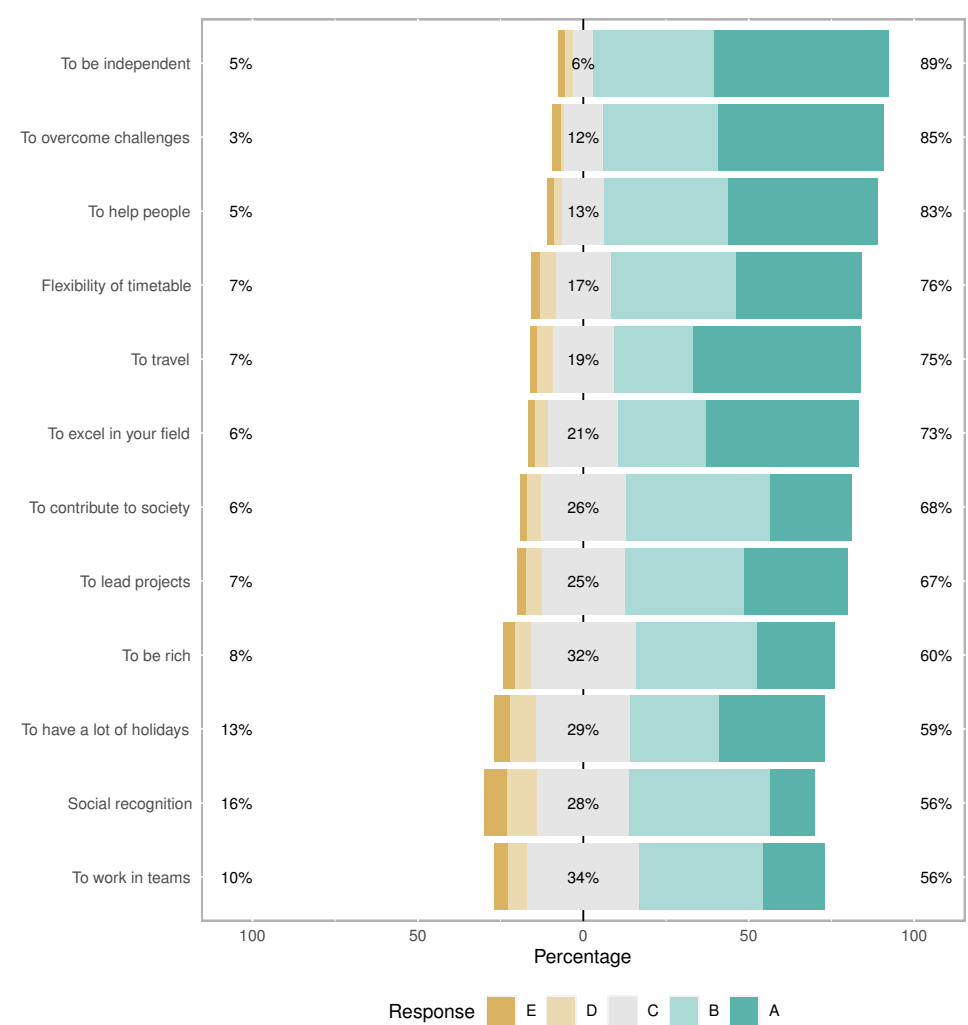

Figure A10. Goals to reach in the future for higher education boys (Block 1). 

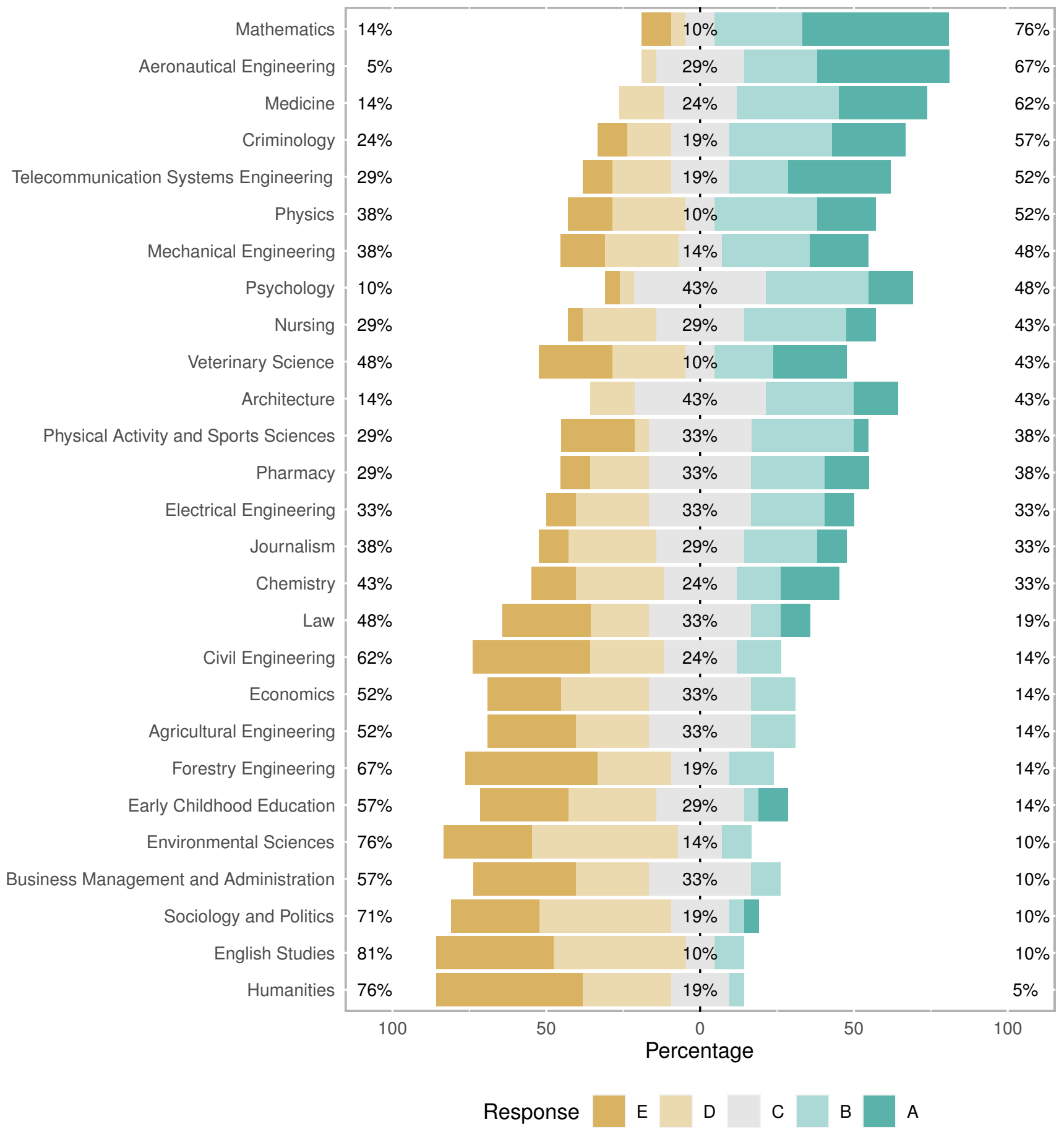

Figure A11. Higher education girls' interest in studies (Block 2). 

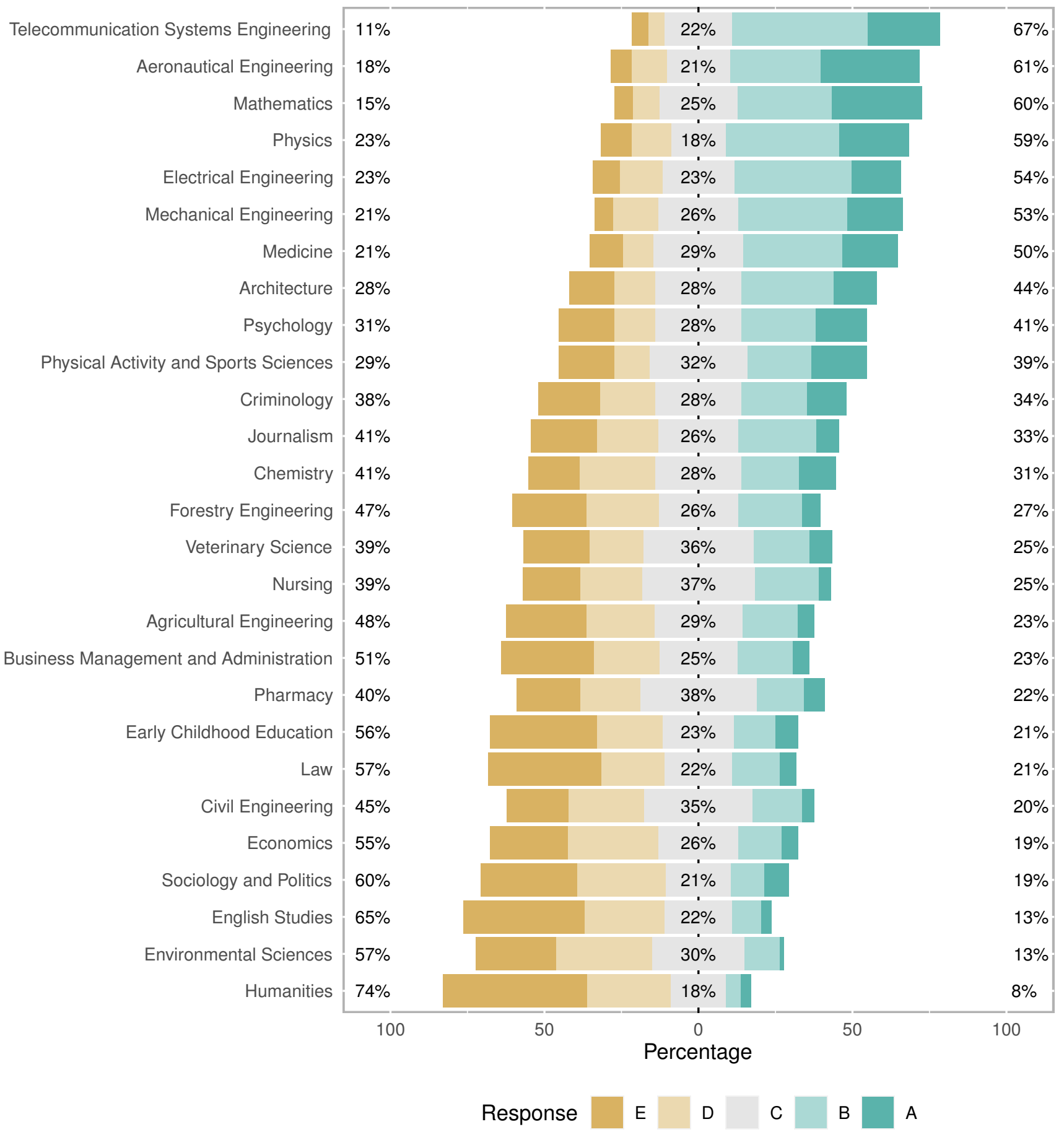

Figure A12. Higher education boys' interest in studies (Block 2). 


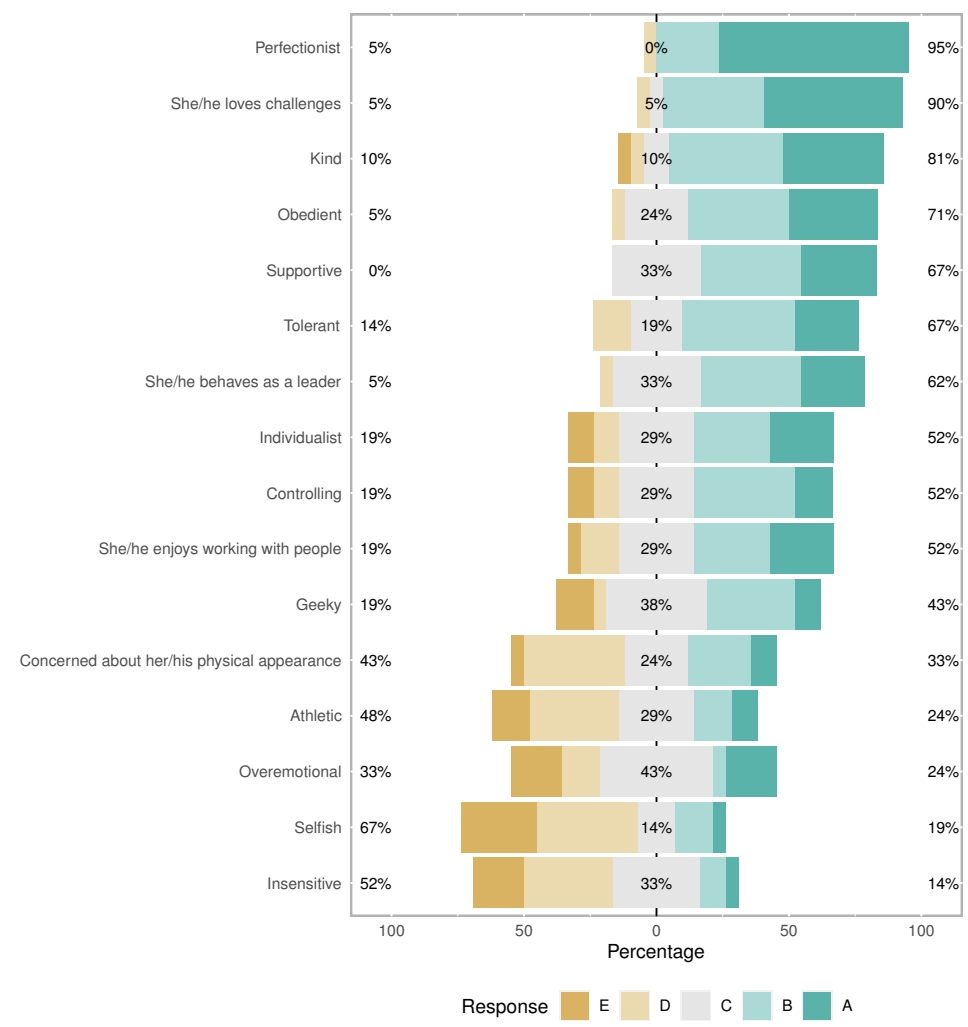

Figure A13. Higher education girls' perception of a professional who works in computer science (Block 3).

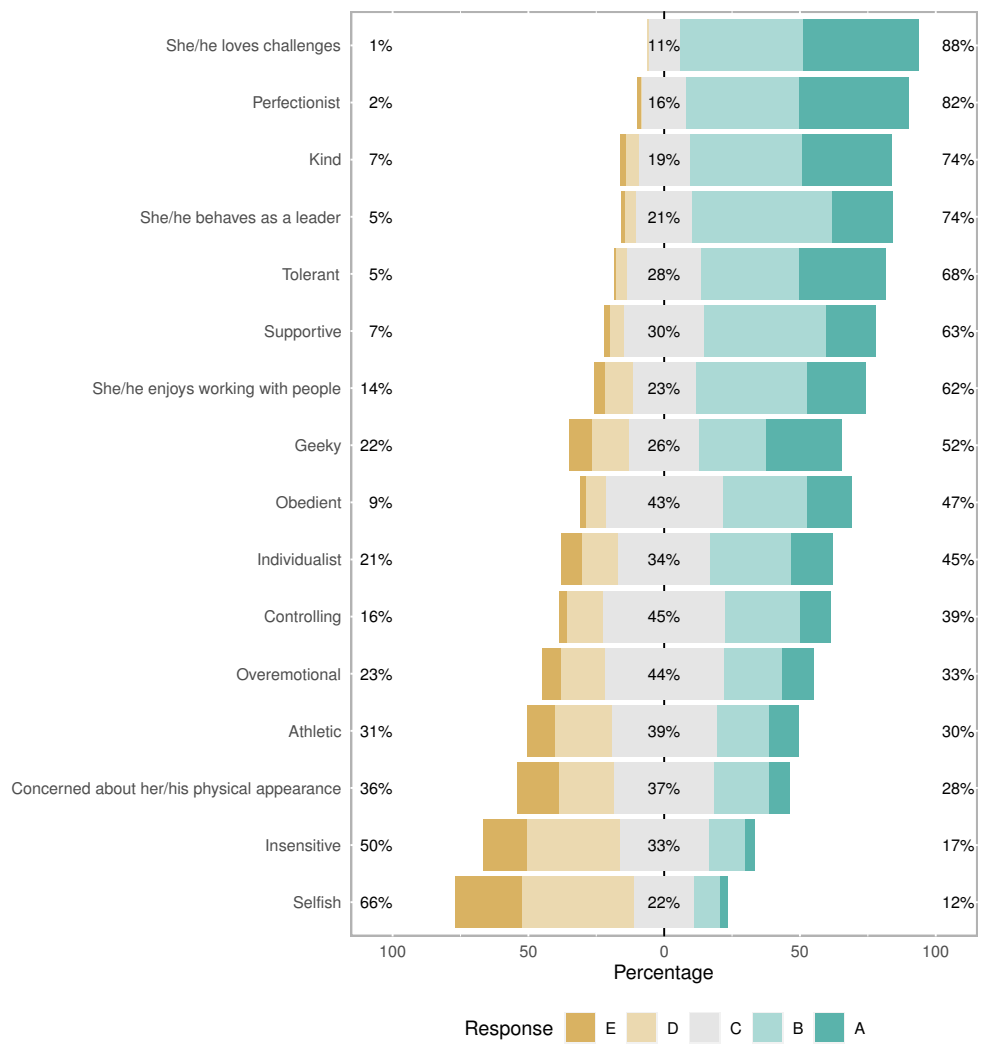

Figure A14. Higher education boys' perception of a professional who works in computer science (Block 3). 


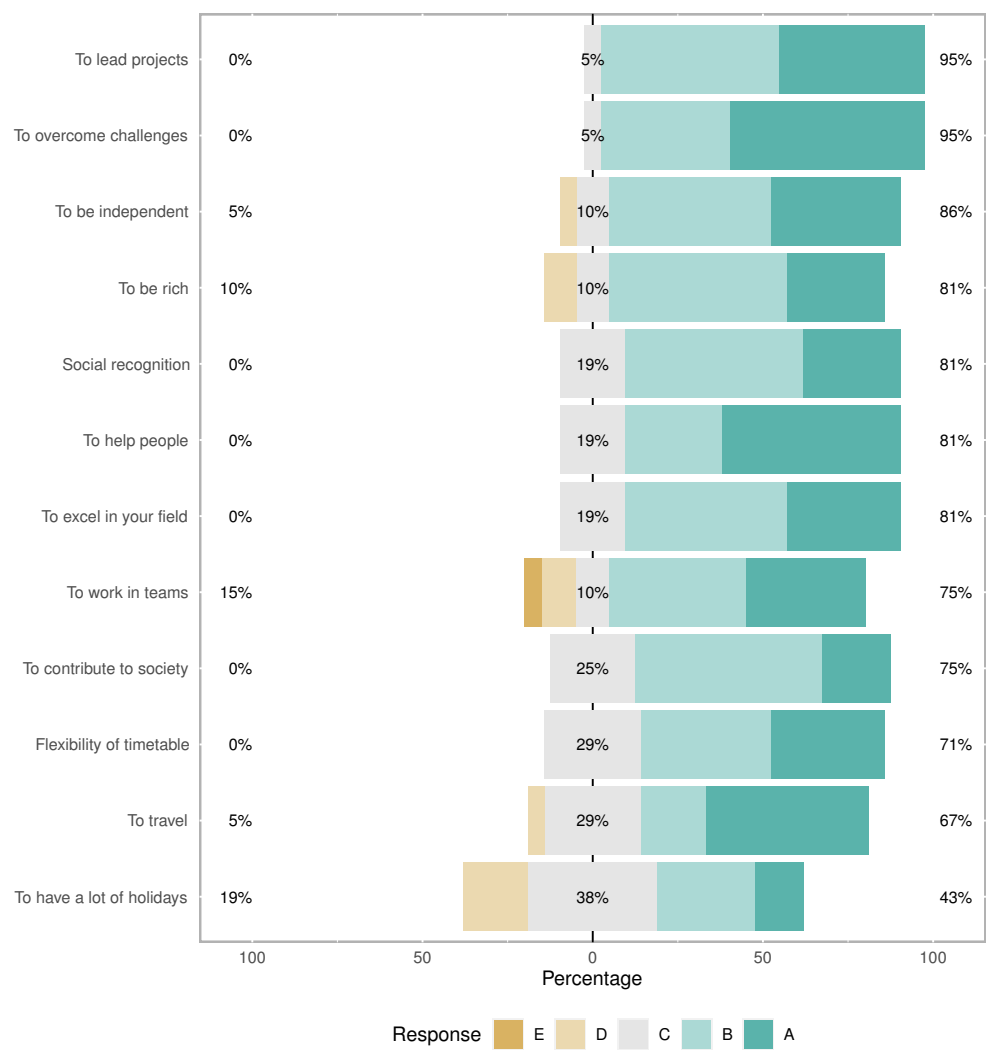

Figure A15. Higher education girls' perception about goals that can be achieved by working in computer engineering (Block 4).

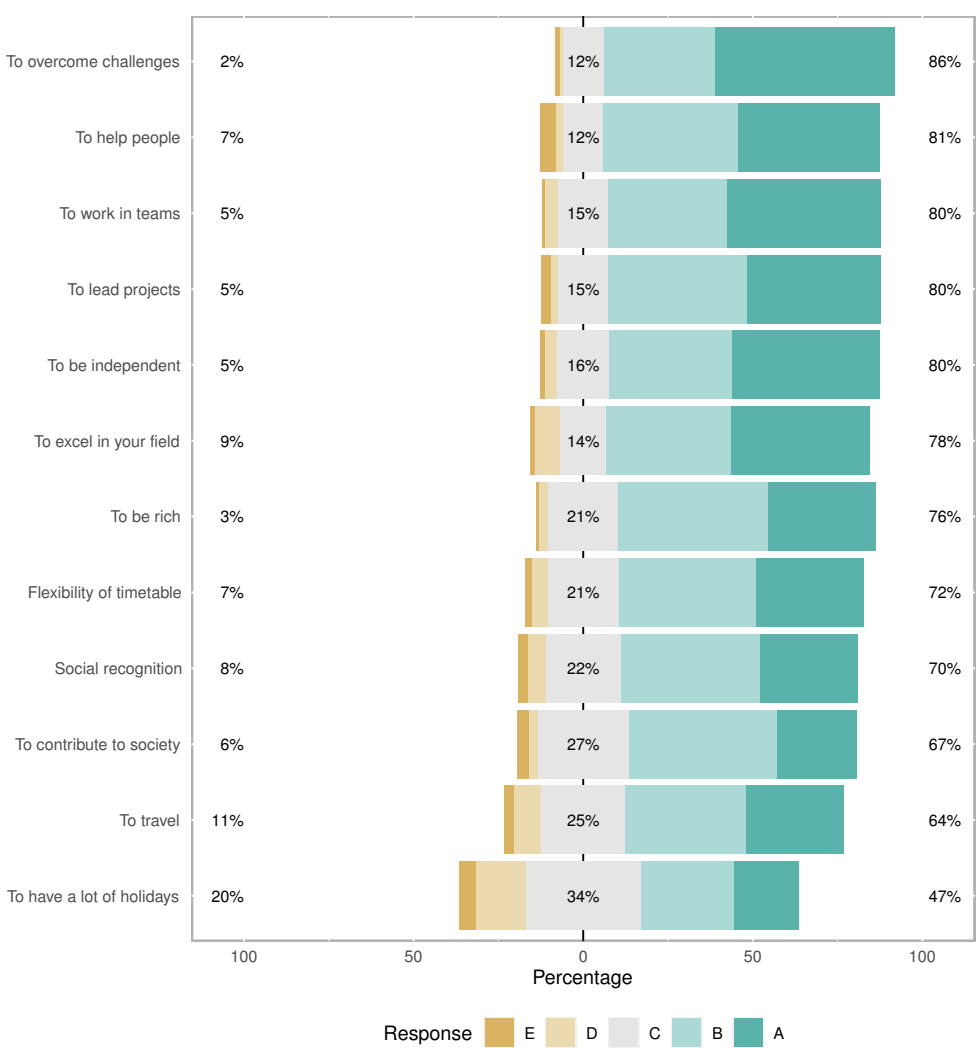

Figure A16. Higher education boys' perception about goals that can be achieved by working in computer engineering (Block 4). 


\section{References}

1. United Nations. Transforming Our World: The 2030 Agenda for Sustainable Development; United-Nations: New York, NY, USA, 2020; Available online: https:/ / sustainabledevelopment.un.org (accessed on 28 July 2021).

2. AAUW. The STEM Gap: Women and Girls in Science, Technology, Engineering and Math; AAUW: Washington, DC, USA, 2020; Available online: https:/ / www.aauw.org/resources/research/the-stem-gap/ (accessed on 28 July 2021).

3. Cundiff, J.L.; Vescio, T.K. Gender Stereotypes Influence How People Explain Gender Disparities in the Workplace. Sex Roles 2016, 75, 126-138. [CrossRef]

4. Verdugo-Castro, S.; Sánchez-Gómez, M.C.; García-Holgado, A. Gender gap in STEM sector in pre and university studies of Europe associated with ethnic factor. In Proceedings of the TEEM'18: Sixth International Conference on Technological Ecosystems for Enhancing Multiculturality, Salamanca, Spain, 24-26 October 2018; pp. 984-990. [CrossRef]

5. Botella, C.; Rueda, S.; López-Iñesta, E.; Marzal, P. Gender diversity in STEM disciplines: A multiple factor problem. Entropy 2019, 21, 30. [CrossRef] [PubMed]

6. Godwin, A.; Kirn, A. Identity-based motivation: Connections between first-year students' engineering role identities and future-time perspectives. J. Eng. Educ. 2020, 5, 1-22. [CrossRef]

7. Ajzen, I. The theory of planned behavior. Organ. Behav. Hum. Decis. Process. 1991, 50, 179-211. [CrossRef]

8. Su, R.; Rounds, J.; Armstrong, P.I. Men and Things, Women and People: A Meta-Analysis of Sex Differences in Interests. Psychol. Bull. 2009, 135, 859-884. [CrossRef] [PubMed]

9. García-Holgado, A.; Mena, J.J.; García-Peñalvo, F.J.; González, C. Inclusion of gender perspective in Computer Engineering careers: Elaboration of a questionnaire to assess the gender gap in tertiary education. In Proceedings of the 2018 IEEE Global Engineering Education Conference (EDUCON), Santa Cruz de Tenerife, Spain, 17-20 April 2018; pp. 1547-1554. [CrossRef]

10. Kim, H.; Cho, Y.; Kim, S.; Kim, H.S. Women and men in Computer Science: Geeky proclivities, college rank, and gender in Korea. East Asian Sci. Technol. Soc. Int. J. 2018, 12, 33-56. [CrossRef]

11. Tobar Subía Contento, L.M.; Nohemi Gamez Aparicio, B. The Gender Gap Broad the Path for Women in STEM. In Proceedings of the Eighth International Conference on Technological Ecosystems for Enhancing Multiculturality (TEEM'20), Salamanca, Spain, 21-23 October 2020; Association for Computing Machinery: New York, NY, USA, 2020; pp. 187-192. [CrossRef]

12. Ehrlinger, J.; Plant, E.A.; Hartwig, M.K.; Vossen, J.J.; Columb, C.J.; Brewer, L.E. Do Gender Differences in Perceived Prototypical Computer Scientists and Engineers Contribute to Gender Gaps in Computer Science and Engineering? Sex Roles 2018, 78, 40-51. [CrossRef]

13. Tsan, J.; Boyer, K.E.; Lynch, C.F. How Early Does the CS Gender Gap Emerge? A Study of Collaborative Problem Solving in 5th Grade Computer Science. In Proceedings of the 47th ACM Technical Symposium on Computing Science Education (SIGCSE '16), Memphis, TN, USA, 2-5 March 2016; Association for Computing Machinery: New York, NY, USA, 2016; pp. 388-393. [CrossRef]

14. Cai, Z.; Fan, X.; Du, J. Gender and attitudes toward technology use: A meta-analysis. Comput. Educ. 2017, 105, 1-13. [CrossRef]

15. European Commission. Women in Digital; European Commission: Brussels, Belgium, 2016; Available online: https://ec.europa. eu/digital-single-market/en/women-ict (accessed on 17 July 2021).

16. Eagly, A.H.; Wood, W.; Diekman, A.B. Social role theory of sex differences and similarities: A current appraisa. In The Development Social Psychology of Gender; Lawrence Erlbaum Associates Publishers: Mahwah, NJ, USA, 2000; pp. 123-174.

17. Deaux, K. Sex and gender. Annu. Rev. Psychol. 1985, 36, 49-81. [CrossRef]

18. Thébaud, S.; Charles, M. Segregation, Stereotypes, and STEM. Soc. Sci. 2018, 7, 111. [CrossRef]

19. Fernández-Cézar, R.; Garrido, D.; García-Moya, M.; Gómezescobar, A.; Solano-Pinto, N. Equity or Stereotypes in Science Education? Perspectives from Pre-University Students. Sustainability 2020, 12, 935. [CrossRef]

20. Makarova, E.; Aeschlimann, B.; Herzog, W. The Gender Gap in STEM Fields: The Impact of the Gender Stereotype of Math and Science on Secondary Students' Career Aspirations. Front. Educ. 2019, 4, 60. [CrossRef]

21. Caplan, R.D. Person-environment fit theory and organizations commensurate dimensions, time perspectives, and mechanisms. $J$. Vocat. Behav. 1985, 31, 248-267. [CrossRef]

22. Schenider, B. The people make the place. Pers. Psychol. 1987, 40, 437-453. [CrossRef]

23. Bakan, D. The Duality of Human Existence; Rand McNally Publisher: Chicago, IL, USA, 1966.

24. Hogan, R.; Roberts, B.W. A socioanalytic perspective on person/environment interaction. In New Directions in Person-Environment Psychology; Erlbaum: Mahwah, NJ, USA, 2000; pp. 1-24.

25. Nye, C.; Rounds, J. Vocational Interests in the Workplace: Rethinking Behavior at Work; Routledge: London, UK, 2019. [CrossRef]

26. Armstrong, P.I.; Day, S.X.; McVay, J.P.; Rounds, J. Holland's RIASEC model as an integrative framework for individual differences. J. Couns. Psychol. 2008, 55, 1-18. [CrossRef]

27. Xu, Y.J. Aspirations and application for graduate Education: Gender differences in low-participation STEM disciplines. Res. High. Educ. 2016, 57, 913-942. [CrossRef]

28. Bencheva, N.; Kostadinow, N. Through STEM education and OER to attract the girls in ICT career. In Proceedings of the 29th Annual Conference of the European Association for Education in Electrical and Information Engineering (EAEEIE), Ruse, Bulgaria, 4-6 September 2019. [CrossRef]

29. Olmedo-Torre, N.; Carracedo, F.S.; Ballesteros, M.N.S.; López, D.; Perez-Poch, A.; Lopez-Beltran, M. Do Female Motives for Enrolling Vary According to STEM Profile? IEEE Trans. Educ. 2018, 61, 289-297. [CrossRef] 
30. Benavent, X.; de Ves, E.; Forte, A.; Botella-Mascarell, C.; López-Iñesta, E.; Rueda, S.; Roger, S.; Perez, J.; Portalés, C.; Dura, E.; et al. Girls4STEM: Gender Diversity in STEM for a Sustainable Future. Sustainability 2020, 12, 6051. [CrossRef]

31. Sáinz, M. Se Buscan Ingenieras, Físicas y Tecnólogas; Editorial Ariel. Fundación Telefónica: Madrid, Spain, 2017.

32. Eccles, J.S.; Barber, B.; Jozefowicz, D. Linking gender to educational, occupational, and recreational choices: Applying the Eccles et al. model of achievement-related choices. In Sexism and Stereotypes in Modern Society: The Gender Science of Janet Taylor Spence; American Psychological Association: Washington, DC, USA, 1999; pp. 153-192. [CrossRef]

33. Eagly, A.H.; Steffen, V.J.; Brumer, B.; Rugs, D.; Schafer, J.; Bronner, E.; Winbury, G. Gender stereotypes STEM from the distribution of women and men into social roles. J. Personal. Soc. Psychol. 1984, 46, 735-754. [CrossRef]

34. Navarro, E.; López-Bonal, M.T.; Macià, M.; Caminero, B.; Carrión, C.; Barba-Sánchez, V.; Lozano, M.; Alonso, M.T.; Cambronero, M.E.; Escobar, I.M.; et al. Una experiencia para fomentar la presencia de la Mujer en Informática a través del 11 de Febrero: Aprendiendo igualdad en la ciencia. In Proceedings of the XXIV Jornadas Sobre Enseñanza Universitaria de la Informática (JENUI 2018), Barcelona, Spain, 4-6 July 2018; Volume 3, pp. 311-318. (In Spanish)

35. López, A.J.; Pereira, D. The Value of Transfer of Knowledge in Bridging the Gender Gap in STEM. Sustainability 2021, $13,5426$. [CrossRef]

36. Ayuso, N.; Fillola, E.; Masiá, B.; Murillo, A.C.; Trillo-Lado, R.; Baldassarri, S.; Cerezo, E.; Ruberte, L.; Mariscal, M.D.; VillarroyaGaudó, M. Gender Gap in STEM: A Cross-Sectional Study of Primary School Students' Self-Perception and Test Anxiety in Mathematics. IEEE Trans. Educ. 2021, 64, 40-49. [CrossRef]

37. Arias, E.; Barba-Sánchez, V.; Carrion, C.; Casado, R. Enhancing Entrepreneurship Education in a Master's Degree in Computer Engineering: A Project-Based Learning Approach. Adm. Sci. 2018, 8, 58. [CrossRef]

38. Kijima, R.; Yang-Yoshihara, M.; Maekawa, M. Using design thinking to cultivate the next generation of female STEAM thinkers. Int. J. STEM Educ. 2021, 8, 1-15. [CrossRef] 